\title{
Data compilation of fluxes of sedimenting material from sediment traps in the Atlantic Ocean
}

\author{
S. Torres Valdés ${ }^{1}$, S. C. Painter ${ }^{1}$, A. P. Martin ${ }^{1}$, R. Sanders ${ }^{1}$, and J. Felden ${ }^{2}$ \\ ${ }^{1}$ Ocean Biogeochemistry and Ecosystems Research Group. National Oceanography Centre. European Way, \\ Southampton, SO14 3ZH, UK \\ ${ }^{2}$ Center for Marine Environmental Sciences. Universität Bremen. Leobener Strasse, POP 330 440, 28359 \\ Bremen, Germany \\ Correspondence to: S. Torres Valdés (sinhue@ noc.ac.uk)
}

Received: 14 August 2013 - Published in Earth Syst. Sci. Data Discuss.: 9 September 2013

Revised: 3 February 2014 - Accepted: 24 March 2014 - Published: 17 April 2014

\begin{abstract}
We provide a data set assemblage of directly observed and derived fluxes of sedimenting material (total mass, $\mathrm{POC}, \mathrm{PON}, \mathrm{bSiO}_{2}, \mathrm{CaCO}_{3}$, PIC and lithogenic/terrigenous fluxes) obtained using sediment traps. This data assemblage contains over 5900 data points distributed across the Atlantic, from the Arctic Ocean to the Southern Ocean. Data from the Mediterranean Sea are also included. Data were compiled from a variety of sources: data repositories (e.g. BCO-DMO, PANGAEA ${ }^{\circledR}$ ), time-series sites (e.g. BATS, CARIACO), published scientific papers and data provided by the originating principal investigators (PIs). All sources are specified within the combined data set. Data from the World Ocean Atlas 2009 were extracted to coincide with flux data to provide additional environmental information where available. Specifically, contemporaneous data were extracted for temperature, salinity, oxygen (concentration, AOU and percentage saturation), nitrate, phosphate and silicate. Data show a broad range of flux estimates, with marked differences between ocean domains. Data also reveal important differences in the contribution that a given variable provides to the total mass flux, which is relevant towards understanding the factors that control the strength of the biological carbon pump. This data set has been submitted to the data repository PANGAEA ${ }^{\circledR}$ (http://www.pangaea.de), who have made it available under doi:10.1594/PANGAEA.807946.
\end{abstract}

\section{Introduction}

The export of particulate organic carbon (POC) from the sunlit upper layers to the ocean interior (deep waters and deep ocean sediments), known as the biological carbon pump (BCP), is an important component of the global carbon cycle. However, the BCP is not well constrained, with estimates of carbon transport ranging from 3.4-4.7 (Eppley and Peter-

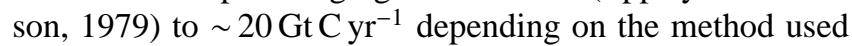
(e.g. Laws et al., 2000). In the North Atlantic alone, estimates of the BCP range fourfold from 0.55 to $1.94 \mathrm{Gt} \mathrm{C} \mathrm{yr}^{-1}$, representing 10-20\% of global export fluxes (Sanders et al., 2014). The uncertainty in these estimates reflects the sparseness of observations and to a smaller extent the variety of methods employed.
Currently, several independently compiled data sets of export flux exist but they reside in separate data repositories as individual data sets. Given the importance of the BCP for carbon storage and the need to further constrain its magnitude, we have attempted to bring together into a single compilation, all data currently available on POC fluxes (and related variables) obtained from sediment-trap deployments in the Atlantic Ocean, which includes the adjacent Arctic Ocean, the Atlantic sector of the Southern Ocean, and the Mediterranean Sea (as an adjacent sea). This data set assemblage was put together as part of the EU FP7 (Seventh Framework Programme) EURO-BASIN (Basin-scale Analysis, Synthesis and INtegration) programme (Work Package 2). Data were obtained from a variety of sources including data repositories (e.g. BCO-DMO, PANGAEA ${ }^{\circledR}$ ), time-series sites (e.g. BATS, CARIACO), published scientific papers and directly 
from the originating PIs. All sources are specified within the data set.

\section{Data}

Observational studies of export often make use of sediment traps. These are deployed at depths of interest in order to collect particles sinking through the water column. Upon recovery, particles are then analysed primarily to determine their carbon content, but additionally the nitrogen content is also easily obtained. The quantities of ballasting material such as calcium carbonate and opal are also increasingly important variables. The flux rate of material captured by a trap can be calculated from knowledge of the duration a trap is deployed for and the aperture of the trap itself. By obtaining export fluxes at different depths, the efficiency of the carbon pump can be evaluated simply as the fraction of the flux leaving the surface that makes it to a given depth.

\subsection{Data sources}

The data assemblage presented here includes variables commonly measured in studies concerning export production. These include total mass (Tot_Mass) flux, POC flux, particulate organic nitrogen $(\mathrm{PON})$ flux, biogenic silica $\left(\mathrm{bSiO}_{2}\right)$ flux, calcium carbonate $\left(\mathrm{CaCO}_{3}\right)$ flux, particulate inorganic carbon (PIC) flux, and terrigenous or lithogenic (Terr/Litho) material flux. Most data were obtained from data repositories and individual time-series websites. A total of 2679 data points ( $45 \%$ of total) were derived from 32 smaller data sets obtained from the Data Publisher for Earth and Environmental Science (PANGAEA ${ }^{\circledR}$ ) at http://www.pangaea.de; 111 data points $(1.9 \%)$ were obtained from the Biological and Chemical Oceanography Data Management Office (BCODMO) at http://bcodmo.org (Lee et al., 2009a, b); 1755 data points $(29.5 \%)$ were obtained from the Carbon Retention In A Colored Ocean Project Ocean Time Series (CARIACO) at http://www.imars.usf.edu/CAR (Montes et al., 2012); and 784 data points $(13.2 \%)$ from the Bermuda Atlantic Time Series (BATS) at http://bats.bios.edu. Data (428 data points, $7.2 \%$ ) were also obtained from published journal articles (e.g. Fischer et al., 2000; Bory et al., 2001; Hwang et al., 2009). Finally, a few data sets (190 data points, $3.2 \%$ ) were directly obtained from Principal Investigators (Bauerfeind et al., 2009; Lampitt et al., 2010). These combined data sets provide 5947 data points of variables related to export production. In this compilation, a "data point" is an independent measurement or calculation of a given variable. The full data set is organised in columns as indicated in Table 1. The names and acronyms of variables as presented in this table are the most commonly used and least ambiguous terms. Though not all individual data sets contain all the variables listed in Table 1. The total number of data points per variable are presented in Table 2. POC flux contains the largest number of observations (5206 data points) and PIC flux the lowest (1048 data points).

\subsection{Methods commonly employed}

Across data sets there is considerable inconsistency in the names of variables and reported units. For this compilation we have attempted, to the best of our knowledge, to identify the variable that was actually being dealt with. For instance "biogenic particulate silicon" vs. "biogenic particulate silica", with the first referring to the element silicon ( $\mathrm{Si}$ ) and the second referring to the mineral silica $\left(\mathrm{SiO}_{2}\right)$. Upon careful examination of such cases, when enough information was available to identify the correct variable, that variable was standardised so that it is internally consistent within this compilation (e.g. all Si related fluxes are consistently reported as $\mathrm{SiO}_{2}$ ). In cases where available information was insufficient to clarify ambiguity, data sets were excluded from the compilation.

\subsubsection{Sediment-trap types}

The data include observations from a range of named sediment-trap designs: moored automatic Kiel sediment traps (Bauerfeind et al., 2009; Bauerfeind and Nöthig, 2011), cone-shaped SMT $230 \mathrm{Kiel}$ and Mark VI/V traps (Wefer and Fischer, 1993), cone-shaped multi-sampling SMT 230 KMU traps (Romero et al., 2002; Fahl and Nöthig, 2007), conical particle interceptor traps (Antia et al., 1999), conical sediment McLane Mark-7 traps (Hwang et al., 2009), drifting Technicap PPS 5 sediment traps (Goutx et al., 2000), Kiel HDW traps (Jonkers et al., 2010), large-aperture timeseries Kiel-type traps (Fischer et al., 2000, 2002; Iversen et al., 2010), Mark-VII automated sediment trap (CARIACO), McLane Mark 78G-21 (Jonkers et al., 2010), multisample moored conical traps (Bory et al., 2001), Parflux Mark 7G-13 time-series sediment trap (Honjo and Manganini, 1993; Jickells, 2003a, b, c, d; Lampitt et al., 2001, 2010), Aquatec Kiel-type sediment trap (Neuer et al., 1997, 2007), indented rotary sphere (IRS) settling velocity and time-series mode sediment traps (Peterson et al., 2005; Goutx et al., 2007; Lee et al., 2009a, b), SMT 234 Aquatec Meerestechnik Kiel trap (Helmke et al., 2005), surface-tethered particle interceptor traps (BATS), and PPS-5 traps (Jonkers et al., 2010). Information is sometimes insufficient to ascertain whether two models are identical. In many studies and within the various data sources, trap specifications are not described. Nevertheless, the specifications of the traps listed above are summarised briefly in Tables 3 and 4 .

\subsubsection{Sample collection procedure}

Before deployment, the collecting cups of sediment traps are filled with ambient seawater. $\mathrm{NaCl}$ is typically added to increase the salinity to 40 (Antia et al., 1999; 
Table 1. Data set column headers. All fluxes are reported as per day over the period of deployment. We note that only at BATS are samples collected in triplicate. Hence, other than BATS, data under the "replicate 1" and "average" headers contain the same information. Not applicable is denoted NA.

\begin{tabular}{|c|c|c|c|}
\hline Data column & Label/Variable & Units & Description \\
\hline 1 & ID & NA & Data point reference number. \\
\hline 2 & $\begin{array}{l}\text { Cruise/Project/Area/ } \\
\text { STN/ Trap }\end{array}$ & NA & $\begin{array}{l}\text { Cruise reference number or name, name of data, originating } \\
\text { project, area where data was collected from, station, trap ID } \\
\text { (depending on available information). }\end{array}$ \\
\hline 3 & yyyymmdd 1 & NA & Date in the format year month day of sediment-trap deployment. \\
\hline 4 & yyyymmdd 2 & NA & Date in the format year month day of sediment-trap recovery. \\
\hline 5 & Duration & Days & Duration of sediment-trap deployment. \\
\hline 6 & Lat & ${ }^{\circ} \mathrm{N}$ & Decimal latitude of sediment-trap deployment. \\
\hline 7 & Long & ${ }^{\circ} \mathrm{E}$ & Decimal longitude of sediment-trap deployment. \\
\hline 8 & Depth & $\mathrm{m}$ & Depth of sediment-trap deployment. \\
\hline 9 & Samp_id1 & NA & Sample/cup ID replicate 1. \\
\hline 10 & Samp_id2 & NA & Sample/cup ID replicate 2 (if available). \\
\hline 11 & Samp_id3 & NA & Sample/cup ID replicate 3 (if available). \\
\hline 12 & Tot_Mass1 & $\mathrm{mg} \mathrm{m}^{-2} \mathrm{~d}^{-1}$ & Total mass flux replicate 1. \\
\hline 13 & Tot_Mass2 & $\mathrm{mg} \mathrm{m}^{-2} \mathrm{~d}^{-1}$ & Total mass flux replicate 2 (if available). \\
\hline 14 & Tot_Mass3 & $\mathrm{mg} \mathrm{m}^{-2} \mathrm{~d}^{-1}$ & Total mass flux replicate 3 (if available). \\
\hline 15 & Tot_Mass_av & $\mathrm{mg} \mathrm{m}^{-2} \mathrm{~d}^{-1}$ & Total mass flux average. \\
\hline 16 & Tot_Mass_stdev & $\mathrm{mg} \mathrm{m}^{-2} \mathrm{~d}^{-1}$ & Total mass standard deviation. \\
\hline 17 & POC_1 & $\mathrm{mg} \mathrm{m}^{-2} \mathrm{~d}^{-1}$ & Particulate organic carbon flux replicate 1. \\
\hline 18 & POC_2 & $\mathrm{mg} \mathrm{m}^{-2} \mathrm{~d}^{-1}$ & Particulate organic carbon flux replicate 2 (if available). \\
\hline 19 & POC_3 & $\mathrm{mg} \mathrm{m}^{-2} \mathrm{~d}^{-1}$ & Particulate organic carbon flux replicate 3 (if available). \\
\hline 20 & POC_Av & $\mathrm{mg} \mathrm{m}^{-2} \mathrm{~d}^{-1}$ & Particulate organic carbon flux average. \\
\hline 21 & POC__stdev & $\mathrm{mg} \mathrm{m}^{-2} \mathrm{~d}^{-1}$ & Particulate organic carbon flux standard deviation. \\
\hline 22 & PON_1 & $\mathrm{mg} \mathrm{m}^{-2} \mathrm{~d}^{-1}$ & Particulate organic nitrogen flux replicate 1. \\
\hline 23 & PON_2 & $\mathrm{mg} \mathrm{m}^{-2} \mathrm{~d}^{-1}$ & Particulate organic nitrogen flux replicate 2 (if available). \\
\hline 24 & PON_3 & $\mathrm{mg} \mathrm{m}^{-2} \mathrm{~d}^{-1}$ & Particulate organic nitrogen flux replicate 3 (if available). \\
\hline 25 & PON_Av & $\mathrm{mg} \mathrm{m}^{-2} \mathrm{~d}^{-1}$ & Particulate organic nitrogen flux average. \\
\hline 26 & PON_stdev & $\mathrm{mg} \mathrm{m}^{-2} \mathrm{~d}^{-1}$ & Particulate organic nitrogen flux standard deviation. \\
\hline 27 & $\mathrm{bSiO}_{2}$ & $\mathrm{mg} \mathrm{m}^{-2} \mathrm{~d}^{-1}$ & Biogenic silica flux average. \\
\hline 28 & $\mathrm{bSiO}_{2} \_\mathrm{stdev}$ & $\mathrm{mg} \mathrm{m}^{-2} \mathrm{~d}^{-1}$ & Biogenic silica flux standard deviation. \\
\hline 29 & $\mathrm{bSiO}_{2}$ Flag & NA & $\begin{array}{l}\text { This flag indicates whether } \mathrm{bSiO}_{2} \text { was corrected or not for dissolution } \\
\text { of the particular fraction in the sample collecting cups of traps (see Sect. 2.2.6). }\end{array}$ \\
\hline 30 & Mol mass ratio & & \\
\hline & silica to silicon & NA & Molecular mass ratio of silica to silicon used to scale $\mathrm{Si}$ to $\mathrm{SiO}_{2}$ (see Sect. 2.2.6). \\
\hline 31 & $\mathrm{CaCO}_{3}$ & $\mathrm{mg} \mathrm{m}^{-2} \mathrm{~d}^{-1}$ & Calcium carbonate flux average. \\
\hline 32 & $\mathrm{CaCO}_{3} \_$stdev & $\mathrm{mg} \mathrm{m}^{-2} \mathrm{~d}^{-1}$ & Calcium carbonate flux standard deviation. \\
\hline 33 & Terr/Litho & $\mathrm{mg} \mathrm{m}^{-2} \mathrm{~d}^{-1}$ & Terrigenous or lithogenic (as reported) material flux average. \\
\hline 34 & Terr_stdev & $\mathrm{mg} \mathrm{m}^{-2} \mathrm{~d}^{-1}$ & Terrigenous or lithogenic material flux standard deviation. \\
\hline 35 & $\mathrm{PIC}$ & $\mathrm{mg} \mathrm{m}^{-2} \mathrm{~d}^{-1}$ & Particulate inorganic carbon flux average. \\
\hline 36 & PIC_stdev & $\mathrm{mg} \mathrm{m}^{-2} \mathrm{~d}^{-1}$ & Particulate inorganic carbon flux standard deviation. \\
\hline 37 & Institution & NA & Affiliation institution of main author and/or data originator (when available). \\
\hline 38 & Trap_Type & NA & Sediment-trap type and/or characteristics as described in the source study or data set \\
\hline 39 & Data source & NA & Link to data source and/or data source information. \\
\hline 40 & doi & NA & Digital object identifier, as generated by PANGAEA ${ }^{\circledR}$. \\
\hline 41 & Event & NA & Event ID, as recorded by PANGAEA ${ }^{\circledR}$. \\
\hline 42 & Notes & NA & Notes. \\
\hline 43 & WOA09_Temp & ${ }^{\circ} \mathrm{C}$ & Temperature from World Ocean Atlas 2009 (WOA09) Climatology. \\
\hline 44 & WOA09_Sal & NA & Salinity from WOA09. \\
\hline 45 & WOA09_DO & $\mu \mathrm{mol} \mathrm{L}-1$ & Dissolved oxygen concentration from WOA09. \\
\hline 46 & WOA09_O ${ }_{2 S A T}$ & $\%$ & Oxygen saturation from WOA09. \\
\hline 47 & WOA09_AOU & $\mu \mathrm{mol} \mathrm{L}-1$ & Apparent oxygen utilisation from WOA09 \\
\hline 48 & WOA09_NO ${ }_{3}^{-}$ & $\mu \mathrm{mol} \mathrm{L}-1$ & Nitrate concentration from WOA09. \\
\hline 49 & WOA09_Si(OH $)_{4}$ & $\mu \mathrm{mol} \mathrm{L}{ }^{-1}$ & Silicate concentration from WOA09. \\
\hline 50 & WOA09_PO ${ }_{4}^{3-}$ & $\mu \mathrm{mol} \mathrm{L}-1$ & Phosphate concentration from WOA09. \\
\hline
\end{tabular}


Table 2. Sinking material flux range, depth range distribution and number of data points available.

\begin{tabular}{|c|c|c|c|c|c|}
\hline \multirow[t]{2}{*}{ Variable } & \multirow[t]{2}{*}{$\begin{array}{l}\text { Number of } \\
\text { data points }\end{array}$} & \multicolumn{2}{|c|}{$\begin{array}{c}\text { Range } \\
\mathrm{mg} \mathrm{m}^{-2} \mathrm{~d}^{-1}\end{array}$} & \multicolumn{2}{|c|}{$\begin{array}{c}\text { Depth range } \\
\mathrm{m}\end{array}$} \\
\hline & & Min. & Max. & Min. & Max. \\
\hline Total mass flux & 4735 & 0.0 & 5584 & 15 & 5031 \\
\hline POC flux & 5202 & 0.0 & 355.7 & 15 & 5031 \\
\hline PON flux & 3996 & 0.0 & 57.9 & 20 & 5031 \\
\hline $\mathrm{bSiO}_{2}$ flux & 2895 & 0.0 & 590.5 & 117 & 5031 \\
\hline PIC flux & 1048 & 0.04 & 81.4 & 117 & 4832 \\
\hline $\mathrm{CaCO}_{3}$ flux & 2631 & 0.0 & 2505.7 & 117 & 5031 \\
\hline Terr/Litho flux & 2166 & 0.0 & 4528.8 & 117 & 5031 \\
\hline
\end{tabular}

Bory and Newton, 2000; Fischer et al., 2002; Fahl and Nöthig, 2007; Neuer et al., 1997). Sufficient formalin to yield 2-3\% formaldehyde ( $\mathrm{wt} / \mathrm{vol})$ or mercuric chloride $(0.14 \%$ final solution) is commonly added to poison the sample to preserve the content (Antia et al., 1999; Fischer et al., 2002; Fahl and Nöthig, 2007; Helmke et al., 2005; Bauerfeind et al., 2009). Following recovery of sediment traps, swimmers (i.e. zooplankton that feed on sedimenting material) are identified and removed from collecting cups (Antia et al., 1999; Bory et al., 2001; Lampitt et al., 2010). Sometimes the samples are sieved ( $1 \mathrm{~mm}$ mesh) to remove large swimmers (e.g. Fischer et al., 2000). Also, samples are sometimes centrifuged following the removal of swimmers and the supernatant is then analysed in order to take into account of any possible dissolution of the material collected (e.g. Waniek et al., 2005). Samples from trap cups are typically split to generate subsamples for the different types of analysis and filtered through preweighed filters which are rinsed with ammonium formate to remove salt and excess formalin (e.g. Bory et al., 2001). The reader is referred to the source references for details of a particular deployment.

\subsubsection{Total mass flux}

Total mass is obtained by weighing the dried matter collected on a filter. As such, it is sometimes referred to as "dry mass". Total mass flux (Tot_Mass flux, $\mathrm{mg} \mathrm{m}^{-2} \mathrm{~d}^{-1}$ ) is calculated as Tot_Mass ${ }_{\text {flux }}=\frac{M_{\mathrm{w}}-\overline{\mathrm{F}_{\mathrm{w}}}}{T \cdot A}$, where $M_{\mathrm{w}}$ is the mass dry weight (mg), $F_{\mathrm{w}}$ is the filter weight (mg), $T$ is the deployment time (days), and $A$ is the aperture trap area $\left(\mathrm{m}^{2}\right)$ (e.g. Bahr et al., 1997).

\subsubsection{POC and PON fluxes}

POC and PON are measured using an elemental CHN analyser (e.g. Fischer et al., 2000; Bahr et al., 1997). The fraction of $\mathrm{C}$ and $\mathrm{N}$ in a given sample is multiplied by Tot_Mass flux to yield POC and PON fluxes $\left(\mathrm{mg} \mathrm{m}^{-2} \mathrm{~d}^{-1}\right)$. Aliquots destined for the determination of POC and PON are filtered onto combusted $\left(6 \mathrm{~h} 400^{\circ} \mathrm{C} \mathrm{GF} / \mathrm{F}\right)$ filters (e.g. Goutx et al.,
2000), or polycarbonate filters ( 25 or $47 \mathrm{~mm}$ ) (e.g. Hwang et al., 2009). Before drying for $\mathrm{CHN}$ analysis, samples are rinsed with $1-6 \mathrm{~N} \mathrm{HCl}$ to remove carbonate (Fischer et al., 2000; Goutx et al., 2000; Bory et al., 2001; Helmke et al., 2005; Iversen et al., 2010). Filters are then dried. Reported drying temperatures vary, but typically, filters are oven dried at $40^{\circ} \mathrm{C}$ (e.g. Goutx et al., 2000), air-dried at $60^{\circ} \mathrm{C}$ overnight (e.g. Hwang et al., 2009), or dried on a hot plate set at $80^{\circ} \mathrm{C}$ (e.g. Wefer and Fischer, 1993; Helmke et al., 2005). Some authors use freeze drying instead (e.g. Fischer et al., 2002; Waniek et al., 2005).

As a term, POC is frequently used interchangeably with "organic carbon $\left(\mathrm{C}_{\mathrm{org}}\right)$ " (e.g. Fischer et al., 1996; Lampitt et al., 2001) or total organic carbon (Wefer and Fischer, 1991; Jonkers et al., 2010). POC, is sometimes estimated as $\mathrm{C}_{\text {org }}=\mathrm{C}_{\text {total }}-\mathrm{C}_{\mathrm{CaCO}_{3}}$ (e.g. Romero et al., 2002), where $\mathrm{C}_{\text {total }}$ is the total carbon content of a sample and $\mathrm{C}_{\mathrm{CaCO}_{3}}$ is the carbon content in calcium carbonate. Similarly, PON is sometimes referred to as total nitrogen (e.g. Lampitt and Antia, 1997; Jonkers et al., 2010). We suggest POC and PON are the most appropriate terms by reasons of method and most common usage in literature.

\subsubsection{Calcium carbonate flux and particulate inorganic Carbon (PIC) flux}

$\mathrm{CaCO}_{3}$ and PIC fluxes are typically derived based on molar mass ratios. $\mathrm{CaCO}_{3}$ has been estimated by multiplying PIC by 8.34 (Lampitt et al., 2010) or by 8.33 (Lampitt et al., 2001; Fischer et al., 2002); i.e. $\frac{\mathrm{CaCO}_{3}}{\mathrm{C}} \approx 8.33$ (though this is not usually explicitly stated). It has also been calculated as $\left(\mathrm{C}_{\text {total }}-\mathrm{C}_{\text {org }}\right) \times 8.33$ (e.g. Wefer and Fischer, 1991; Helmke et al., 2005) following CHN analysis; that is, $\mathrm{PIC} \times \frac{\mathrm{CaCO}_{3}}{\mathrm{C}}$. It has been also determined through mass loss following acidification and then weighing (e.g. Fahl and Nöthig, 2007). Hwang et al. (2009) refer to "biogenic $\mathrm{CaCO}_{3}$ ", which they estimated by multiplying the "biogenic $\mathrm{Ca}$ " by 2.5 ; i.e. the molar mass ratio $\frac{\mathrm{CaCO}_{3}}{\mathrm{Ca}}$. In turn, they obtained "biogenic $\mathrm{Ca}$ " as the difference between total $\mathrm{Ca}$ and lithogenic $\mathrm{Ca}$. The latter being $0.5 \times \mathrm{Al}$, based on the ratio of $\mathrm{Ca}$ to $\mathrm{Al}$ of the average continental crust composition (e.g. Wedepohl, 1995; Rudnick and Gao, 2003). Total inorganic carbon is determined by coulometric titration (Hwang et al., 2009). $\mathrm{CaCO}_{3}$ flux is sometimes corrected if organisms containing calcium carbonate, such as pteropods, are present in the sample (e.g. Bauerfeind et al., 2009).

PIC has been calculated as $12 \%$ carbonate by weight (Antia et al., 1999; Bauerfeind et al., 2009), i.e. the $\mathrm{C}$ content in $\mathrm{CaCO}_{3}$. PIC content has also been calculated from total $\mathrm{Ca}$ concentrations in samples as $\mathrm{CaCO}_{3}$ (Bory et al., 2001). It is also estimated as $\mathrm{C}_{\text {total }}-\mathrm{C}_{\mathrm{org}}$; i.e. the difference between the $\mathrm{C}$ measured in filtered samples without removal of carbonate, and the $\mathrm{C}$ measured in samples treated with $\mathrm{HCl}$. The term "inorganic carbon" as equivalent of PIC is sometimes used 
Table 3. Sediment-trap specifications summary.

\begin{tabular}{|c|c|c|c|c|}
\hline Trap type & $\begin{array}{l}\text { Type of } \\
\text { deployment }\end{array}$ & General specifications & Further information & Used by \\
\hline Kiel type & $\begin{array}{l}\text { Bottom } \\
\text { tethered }\end{array}$ & $\begin{array}{l}\text { Fiberglass-reinforced plastic } \\
\text { baffle, funnel and frame. Baffle } \\
\text { consists of } 20 \mathrm{~mm} \times 20 \mathrm{~mm} \times 120 \mathrm{~mm} \text { cells. } \\
0.5 \mathrm{~m}^{2} \text { aperture, cone with a } 34^{\circ} \\
\text { angle. Bottom of funnel mounted } \\
\text { into a PTFE (polytetrafluoroethylene) transfer cylinder. } \\
\text { Rotary sampler with } 21 \text { collecting } \\
\text { bottles. }\end{array}$ & $\begin{array}{l}\text { Zeitzschel et al. (1978) } \\
\text { Kremling et al. (1996) }\end{array}$ & $\begin{array}{l}\text { Antia et al. (1999), } \\
\text { Bauerfeind and Nöthig (2011) } \\
\text { Bauerfeind et al. (2009) } \\
\text { Fischer (2005, 2003a, b, c, d) } \\
\text { Fischer et al. (2002, 2000) } \\
\text { Iversen et al. (2010) } \\
\text { Jonkers et al. (2010) } \\
\text { Neuer et al. (1997, 2007) } \\
\text { Peinert et al. (2001) } \\
\text { Raab (2003) } \\
\text { von Bodungen et al. (1995) } \\
\text { Waniek et al. (2005) } \\
\text { Žarić et al. (2005) }\end{array}$ \\
\hline $\begin{array}{l}\text { Parflux } \\
\text { Mark V }\end{array}$ & $\begin{array}{l}\text { Bottom } \\
\text { tethered }\end{array}$ & $\begin{array}{l}1.15 \mathrm{~m}^{2} \text { aperture. } 520 \text { baffle } 52 \mathrm{~mm} \\
\text { diameter cells with a } 2.5 \text { aspect ratio. } \\
36^{\circ} \text { cone angle. Rotary sampler with } \\
12,13 \text { or } 25 \text { sample cups. }\end{array}$ & $\begin{array}{l}\text { Honjo and Doherty (1988) } \\
\text { Newton et al. (1994) } \\
\text { www.mclanelabs.com }\end{array}$ & $\begin{array}{l}\text { Bory et al. (2001) } \\
\text { CARIACO time series } \\
\text { Fischer }(2005,2003 a, b, c, d) \\
\text { Fischer et al. }(2002,2000)\end{array}$ \\
\hline Parflux & & $0.5 \mathrm{~m}^{2}$ aperture. 368 baffle $25 \mathrm{~mm}$ & & Honjo and Manganini (1993) \\
\hline Mark VI & & $\begin{array}{l}42^{\circ} \text { cone angle. Rotary sampler with } \\
13 \text { sample cups. }\end{array}$ & & $\begin{array}{l}\text { Hwang et al. (2009) } \\
\text { Jickells et al. (1996) }\end{array}$ \\
\hline $\begin{array}{l}\text { Parflux } \\
\text { Mark } 78\end{array}$ & & $\begin{array}{l}0.5 \mathrm{~m}^{2} \text { aperture. } 268 \text { baffle } 25 \mathrm{~mm} \\
\text { diameter cells with a } 2.5 \text { aspect ratio. } \\
41^{\circ} \text { cone angle. Rotary sampler with } \\
21 \text { or } 13 \text { wide sample cups. }\end{array}$ & & $\begin{array}{l}\text { Jonkers et al. (2010) } \\
\text { Lampitt and Antia (1997) } \\
\text { Lampitt et al. (2001, 2010) } \\
\text { Wefer and Fischer (1991) } \\
\text { Žarić et al. (2005) }\end{array}$ \\
\hline $\begin{array}{l}\text { SMT } 230 \\
\text { SMT } 234\end{array}$ & $\begin{array}{l}\text { Bottom } \\
\text { tethered }\end{array}$ & $\begin{array}{l}0.5 \mathrm{~m}^{2} \text { aperture. } 41 \text { sample cups. } \\
0.5 \mathrm{~m}^{2} \text { aperture. } 21 \text { sample cups. } \\
\text { Both with a } 34^{\circ} \text { cone angle. }\end{array}$ & $\begin{array}{l}\text { www.kum-kiel.de } \\
\text { Helmke et al. (2010) }\end{array}$ & $\begin{array}{l}\text { Fahl and Nöthig (2007) } \\
\text { Helmke et al. (2005) } \\
\text { Romero et al. (2002) } \\
\text { Wefer and Fischer (1991) }\end{array}$ \\
\hline $\begin{array}{l}\text { Technicap PPS } 3 \\
\text { Technicap PPS } 5\end{array}$ & $\begin{array}{l}\text { Bottom } \\
\text { Bottom } \\
\text { and surface* } \\
\text { tethered }\end{array}$ & $\begin{array}{l}0.125 \mathrm{~m}^{2} \text { aperture, cylindro-conical } \\
\text { collector with a } 2.5 \text { aspect ratio } \\
\text { (unbaffled). } 1 \mathrm{~m}^{2} \text { aperture, } 8 \mathrm{~mm} \\
\text { baffle cell diameter. Made of Fibreglass. }\end{array}$ & $\begin{array}{l}\text { www.technicap.com } \\
\text { Miquel et al. (2011) }\end{array}$ & $\begin{array}{l}\text { Goutx et al. }(2000)^{*} \\
\text { Jonkers et al. }(2010) \\
\text { DYFAMED time series }\end{array}$ \\
\hline $\begin{array}{l}\text { Indented Rotary } \\
\text { Sphere; IRS }\end{array}$ & $\begin{array}{l}\text { Surface } \\
\text { tethered }\end{array}$ & $\begin{array}{l}\text { It consists of a } 15 \mathrm{~cm} \text { diameter cylindrical } \\
\text { particle interceptor. An indented rotating } \\
\text { sphere valve about halfway down the } \\
1.7 \mathrm{~m} \text { total length of the trap, which leads } \\
\text { to a skewed funnel delivering collected } \\
\text { particles to a sample carrousel. The trap } \\
\text { can be set to time series (TS) or settling } \\
\text { velocities (SV) mode. }\end{array}$ & Peterson et al. $(2005,2009)$ & Lee et al. (2009b) \\
\hline
\end{tabular}

in the literature too (e.g. Lampitt and Antia, 1997; Lampitt et al., 2001).

\subsubsection{Biogenic silica flux}

Biogenic silica requires more care relative to other variables. This derives from the fact that multiple names and terms are used rather ambiguously. For this compilation we attempted, to the best of our knowledge, to identify the variable that was being dealt with in each instance. We based our evaluation on the methods used and in some cases by contacting originating PIs.
Biogenic silica is typically measured as dissolved silicon with colorimetric methods following extraction from particulate material. Several methods exists (e.g. Eggimann et al., 1980; DeMaster, 1981; Mortlock and Froelich, 1989; Müller and Schneider, 1993), but the methods most commonly used are based on an the alkaline digestion method of Mortlock and Froelich (1989) (e.g. Antia et al., 1999; Bory et al., 2001; Salter et al., 2010) or the sequential leaching method of DeMaster (1981) as modified by Müller and Schneider (1993) (e.g. Wefer and Fischer, 1991, 1993; Romero et al., 2002; Helmke et al., 2005). The former is based on the extraction of opaline silicon into a $2 \mathrm{M}$ solution of $\mathrm{Na}_{2} \mathrm{CO}_{3}$ at $85^{\circ} \mathrm{C}$ for $5 \mathrm{~h}$, after which the digested sample is measured with 
Table 4. Sediment-trap specifications summary.

\begin{tabular}{|c|c|c|c|c|}
\hline Trap type & $\begin{array}{l}\text { Type of } \\
\text { deployment }\end{array}$ & General specifications & Further information & Used by \\
\hline $\begin{array}{l}\text { Particle } \\
\text { interceptor } \\
\text { traps (PIT) }\end{array}$ & $\begin{array}{l}\text { Surface } \\
\text { tethered }\end{array}$ & $\begin{array}{l}\text { Polycarbonate cylinder, } 0.0039 \mathrm{~m}^{2} \\
\text { aperture. Plastic baffling consists of } \\
\text { circular openings of } 1.2 \mathrm{~cm} \text { diameter. } \\
\text { The base holds a } 90 \mathrm{~mm} \text { Poretics } \\
\text { polycarbonate membrane filter. } \\
\text { The trap frame holds up } 15 \text { cylinders. }\end{array}$ & Bahr et al. (1997) & BATS \\
\hline $\begin{array}{l}\text { Surface } \\
\text { tethered } \\
\text { traps }\end{array}$ & $\begin{array}{l}\text { Surface } \\
\text { tethered }\end{array}$ & $\begin{array}{l}480 \mathrm{~mm} \text { cylinders with a } 125 \mathrm{~mm} \\
\text { diameter, and } 200 \mathrm{~mm} \text {-long baffle. } \\
\text { Inserted in each cylinder are four } 480 \\
\text { mm-long, } 50 \mathrm{~mm} \text {-diameter smaller } \\
\text { cylinders. }\end{array}$ & Neuer et al. (2007) & Neuer et al. (2007) \\
\hline $\begin{array}{l}\text { OSU } \\
\text { traps }\end{array}$ & $\begin{array}{l}\text { Bottom } \\
\text { tethered }\end{array}$ & $\begin{array}{l}2: 1 \text { height : diameter fiberglass plastic } \\
\text { cone, } 1 \mathrm{~cm} \times 5 \mathrm{~cm} \text { baffle, } 10 \mathrm{~cm} \text { aperture. } \\
\text { Oregon State University (OSU)-made traps } \\
\text { based on Soutar et al. (1977). }\end{array}$ & Dymond and Lyle (1994) & Dymond and Lyle (2003a, b) \\
\hline $\begin{array}{l}\text { Unnamed } \\
\text { trap }\end{array}$ & $\begin{array}{l}\text { Bottom } \\
\text { tethered }\end{array}$ & $\begin{array}{l}\text { Small trap, } 118 \mathrm{~mm} \text { diameter cylinder } \\
490 \mathrm{~mm} \text { working part and baffle. } \\
\text { Lower part is conical and connected } \\
\text { to a sample collecting flask. }\end{array}$ & $\begin{array}{l}\text { Lisitsyn et al. (1995) } \\
\text { Stein (1999) }\end{array}$ & Shevchenko (2000) \\
\hline $\begin{array}{l}\text { Unnamed } \\
\text { drifters }\end{array}$ & $\begin{array}{l}\text { Surface } \\
\text { tethered }\end{array}$ & No information available & & $\begin{array}{l}\text { Irwin }(2002 \mathrm{a}, \mathrm{b}) \\
\text { Martin }(2003 \mathrm{a}, \mathrm{b}, \mathrm{c}) \\
\text { NGOFS and Tande (2003) } \\
\text { OMEX and Wassmann }(2004 \mathrm{a}, \mathrm{b}, \mathrm{c}, \mathrm{d}) \\
\text { OMEX and Wassmann }(2004 \mathrm{e}, \mathrm{f}, \mathrm{g}, \mathrm{h})\end{array}$ \\
\hline $\begin{array}{l}\text { Unnamed } \\
\text { traps }\end{array}$ & $\begin{array}{l}\text { Bottom } \\
\text { tethered }\end{array}$ & No information available & & $\begin{array}{l}\text { Tett (2005) } \\
\text { Thomsen and von Bodungen }(2001 \mathrm{a}, \mathrm{b}, \mathrm{c})\end{array}$ \\
\hline
\end{tabular}

standard photometric methods using an autoanalyser (Mortlock and Froelich, 1989). The latter is an automated method designed to extract $\mathrm{Si}$ from a broader range of compounds. The extraction is carried out with a $1 \mathrm{M}$ solution of $\mathrm{NaOH}$ also at $85^{\circ} \mathrm{C}$, but the digestion solution is cycled from and to a digestion vessel; a proportion runs through an autoanalyser and another fraction is circulated back to the digestion vessel until extraction is completed (Müller and Schneider, 1993). There is an issue however, associated with the use of either method. Since the end product of the extraction is $\mathrm{Si}$, this then needs to be "scaled" back to silica $\left(\mathrm{SiO}_{2}\right)$. The method by Mortlock and Froelich (1989) uses a factor of 2.4 (the molar mass ratio of $\frac{\mathrm{SiO}_{2} \cdot 0.4 \mathrm{H}_{2} \mathrm{O}}{\mathrm{Si}}$ ), which accounts for the average water content of diatomaceous silica. The method by Müller and Schneider (1993) instead uses the molar mass ratio of $\frac{\mathrm{SiO}_{2}}{\mathrm{Si}} \approx 2.139$. Another method used is that of Koning et al. (2002) (e.g. Jonkers et al., 2010), which is based on the method by Müller and Schneider (1993). Given the molar mass ratios adopted, and given that some data sets report biogenic $\mathrm{Si}$ rather than biogenic $\mathrm{SiO}_{2}$, which we converted using the molar mass ratio of 2.1 , we include a column in the data assemblage where the ratio is indicated. We did this based on whether a study or source used either of the methods above, except when a "conversion factor" was explicitly stated independently of the digestion method used. When information provided was "unclear" about the ratio used, this is pointed out.

In some cases, dissolved silica is first measured in the water used for the collecting cups. Dissolved silica is then measured again following the trap's recovery in order to correct for any opal dissolution (e.g. Jonkers et al., 2010). However, we note that not all the biogenic silica data in this compilation includes such a correction or its application to the data was not clear. We have flagged these data as follows: 0 when corrections were made, 1 when corrections were not made, and 2 when information was not available to ascertain either.

All calculations in the literature are related to the molar mass ratio of silica or its hydrated form (as above), to elemental silicon. However, the terminology used is rather inconsistent. Hwang et al. (2009) report opal as the result of multiplying "biogenic Si" by 2.4 , where biogenic $\mathrm{Si}$ is the difference between the total $\mathrm{Si}$ and the lithogenic-Si $(3.5 \times \mathrm{Al}$, an approximation of the ratio of $\mathrm{Si}$ to $\mathrm{Al}$ in the continental crust). Bauerfeind et al. (2009) define "biogenic particulate silica (bPSi)" in their abstract, which suggests the compound "silicon dioxide" $\left(\mathrm{SiO}_{2} \cdot n \mathrm{H}_{2} \mathrm{O}\right)$ is being dealt with. However, in the methods section, it is redefined as "biogenic particulate silicon (bPSi)"; hence it is the chemical 
element Si that seems to be dealt with. Further, Opal is defined as $2.1 \times$ bPSI; i.e. the mass ratio $\left(\frac{\mathrm{SiO}_{2}}{\mathrm{Si}}\right)$ multiplied by bPSi (Bauerfeind et al., 2009). The following terms are also commonly used in the literature: " $\mathrm{PSiO}_{2}$ " (von Bodungen et al., 1995; Peinert et al., 2001; Bauerfeind and Nöthig, 2011), " $\mathrm{PSiO}_{2}$ and $\mathrm{BSiO}_{2}$ " (Fischer, 2003a), "PSi" (Fischer, 2005), "BSi" (Ragueneau et al., 2001), " $\mathrm{BSiO}_{2}$ " as the sum of $\mathrm{PSiO}_{2}$ and $\mathrm{DSiO}_{2}$ (e.g. Antia et al., 1999; Lampitt et al., 2001; Honjo and Manganini, 2003a, b, c), "BSiO ${ }_{2}$ " (Lampitt and Antia, 1997), "Opal" (Neuer et al., 1997, 2007), "bPSi or biogenic particulate silicon" (opal $=2.1 \times \mathrm{bPSi})$ (Bauerfeind et al., 2009), "opaline silica" (Lampitt et al., 2010) or "biogenic silica (opal)" (Antia et al., 1999; Fischer et al., 2002; Waniek et al., 2005).

Since the ballasting effect of the mineral $\mathrm{SiO}_{2}$ (opal) is most germane to this database, and since the interest resides in identifying the opal related to particles of biological origin (hence the term "biogenic"), the data we report here is referred to as "biogenic silica" or "biogenic opal". When data was found to be reported as $\mathrm{Si}$, these were converted to $\mathrm{SiO}_{2}$ using the molar mass ratio $\frac{\mathrm{SiO}_{2}}{\mathrm{Si}}$. We suggest the use of lower-case "b" to refer to "biogenic" in combination with the chemical formula $\mathrm{SiO}_{2}$ (i.e. $\mathrm{bSiO}_{2}$ ), since upper-case $\mathrm{B}$ is the chemical symbol for the element Boron. We also suggest that whether samples of $\mathrm{bSiO}_{2}$ are corrected for dissolution or not in the trap-collecting cups should clearly be stated in future studies.

\subsubsection{Lithogenic and/or terrigenous material flux}

Lithogenic fluxes are typically estimated as the difference between the total mass flux and what is termed either "biogenic flux", "biogenic matter" or "organic matter flux"; i.e. $\mathrm{CaCO}_{3}+\mathrm{POC}+\mathrm{BSiO}_{2}$ fluxes (e.g. Antia et al., 1999; Bauerfeind et al., 2009). For this purpose, in deriving "organic matter", POC is sometimes multiplied by 2 (Fischer et al., 2002; Bauerfeind et al., 2009) or 2.5 (e.g. Hwang et al., 2009), as this is considered to give a more representative flux of organic matter but, in the literature, this adjustment would benefit from a fuller explanation. Thus, biogenic flux ( Bio $\left._{\text {flux }}\right)$ is $\mathrm{Bio}_{\text {flux }}=2 \times \mathrm{POC}_{\text {flux }}+\mathrm{CaCO}_{3 \text { flux }}+\mathrm{Opal}_{\text {flux }}$. Lithogenic flux (Litho) is given by Litho $=$ Tot_Mass ${ }_{\text {flux }}-$ Bio $_{\text {Flux }}$. Some researchers estimate the lithogenic material from $\mathrm{Al}$ concentrations, under the assumption it contains $8.4 \% \mathrm{Al}$ (Bory et al., 2001 ) or by multiplying the $\mathrm{Al}$ concentration by 12.15 (e.g. Hwang et al., 2009). The latter is based on the assumption of a crustal $\mathrm{Al}$ composition of $8.2 \%(1 / 12.15=0.082)$.

\subsection{Data standardisation}

This data assemblage contains fluxes from short-duration deployments (hour-days) to longer-duration deployments lasting from months to a year, or over a year. Hence, in order to standardise the data set, all values from long-term deployments, typically reported in grams per square metre per year $\left(\mathrm{g} \mathrm{m}^{-2} \mathrm{yr}^{-1}\right)$ (e.g. Wefer and Fischer, 1991, 1993; Fischer et al., 2000; Fischer, 2005; Peinert et al., 2001), were converted to daily values, i.e. milligrams per square metre per day $\left(\mathrm{mg} \mathrm{m}^{-2} \mathrm{~d}^{-1}\right)$, which is the unit most commonly reported. Long-term deployments, however, can be easily identified; a column is provided which specifies the duration of the deployment. A few daily values were reported in grams per square metre per day $\left(\mathrm{g} \mathrm{m}^{-2} \mathrm{~d}^{-1}\right)$, and these were also converted to milligrams per square metre per day $\left(\mathrm{mg} \mathrm{m}^{-2} \mathrm{~d}^{-1}\right)$ for consistency. In a few instances, POC, PIC, and $\mathrm{bSiO}_{2}$ were reported in moles per square metre per year $\left(\mathrm{mol} \mathrm{m}^{-2} \mathrm{yr}^{-1}\right)$ (e.g. Antia et al., 1999; Dymond and Lyle, 2003a, b; Honjo and Manganini, 2003d, e, f; Fahl and Nöthig, 2007) or millimole per square metre per day $\left(\mathrm{mmol} \mathrm{m}^{-2} \mathrm{~d}^{-1}\right)$ (Martin, 2003a, b, c). Again, for consistency, these were converted to milligrams per square metre per day $\left(\mathrm{mg} \mathrm{m}^{-2} \mathrm{~d}^{-1}\right)$ using the appropriate molecular masses and or molecular mass ratios as required. A column of notes is included, and where unit conversions were done, these are pointed out.

\section{Quality control}

Given that the data compiled here derives from research already published, we assume that the originating authors have already undertaken steps necessary to assure data quality. We point out however, that attention should be paid to the fact that the use of slightly different "conversion factors" for a given variable inherently adds error to the data, with up to $20 \%$ in the case of lithogenic flux when derived as the difference between total mass flux and "organic matter" flux, and where "organic matter" is calculated using conversion factors of 2 or 2.5 (Sect. 2.2.7). In the case of $\mathrm{bSiO}_{2}$, the error generated is $\sim 12 \%$, resulting from the use of $2.1,2.139$ or 2.4 when estimated from $\mathrm{Si}$ (Sect. 2.2.6). We did not attempt to "harmonise" the data by using a unique factor for a given variable, since this would involve modifying the data from that found in the original sources. However, in the light of the different deployment durations and traps used, different analytical methods employed, different calculation approaches and different units reported, here we have tried, as best as possible, to put the data together in a manner allowing users to trace original data sources for further scrutiny and so that users can decide how to handle the data further for the specific questions they may choose to tackle.

\section{Ancillary data}

Where possible, data from the World Ocean Atlas 2009 (WOA09) were extracted to coincide with flux data to provide additional environmental information (http:// www.nodc.noaa.gov/OC5/WOA09/pr_woa09.html). Specifically, data were extracted for temperature, salinity, oxygen (concentration, AOU and percentage saturation), nitrate, phosphate and silicate. The extraction involves linear 


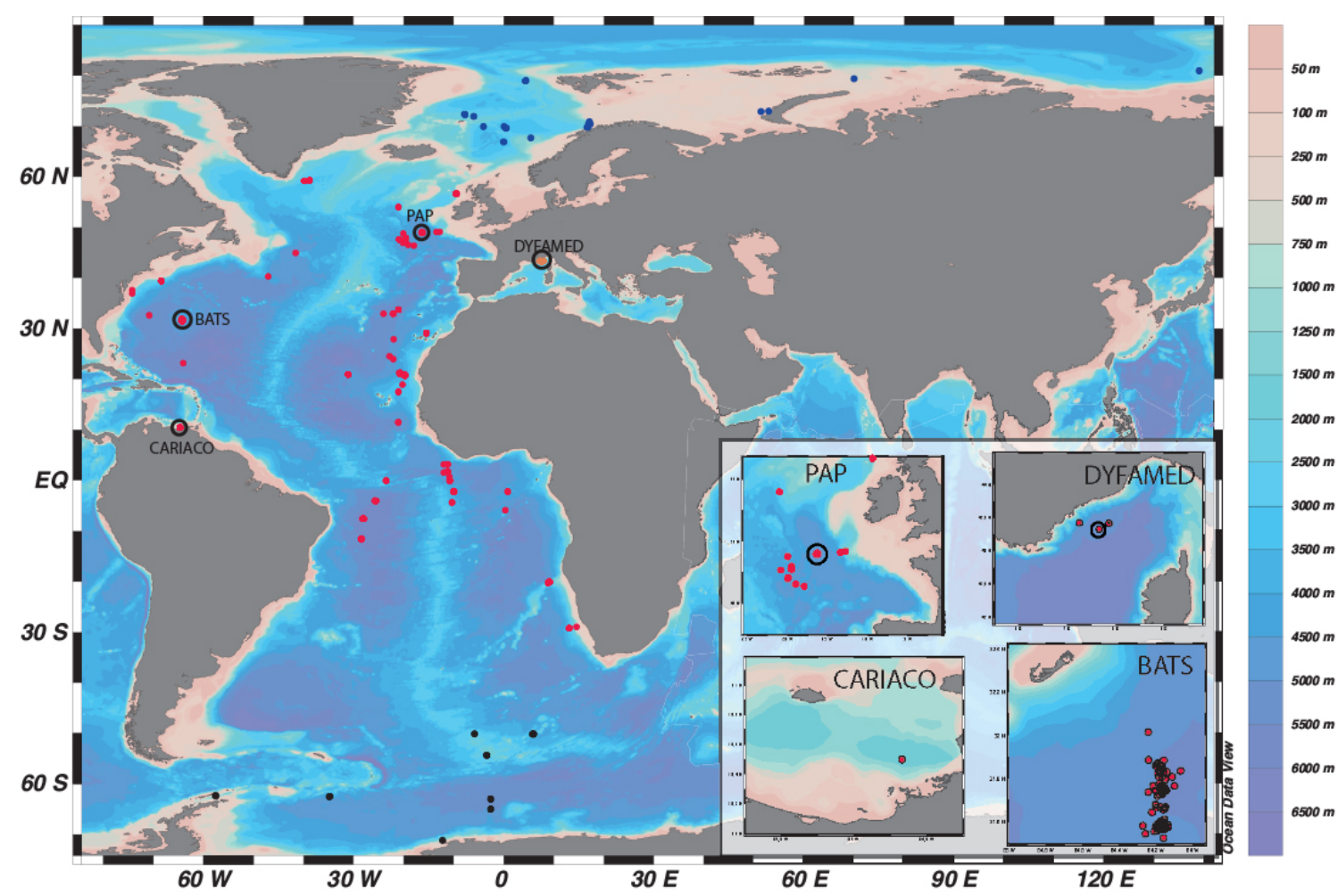

Figure 1. Map showing the location of sediment-trap deployments. Inset figures show expanded maps of regions where the CARIACO, BATS, PAP and DYFAMED time series are located. Locations are colour-coded per ocean domain: Atlantic (red dots), Mediterranean (orange dots), Arctic (blue dots), and Southern Ocean (black dots).

interpolation of WOA09 data to the latitude, longitude and depth of the flux data. Each environmental variable is a weighted average over the period of deployment. Note that as WOA09 is a climatology it cannot provide data for specific years. For example, if a mooring collected flux data from 1 November 1990 until 15 January 1991, the WOA data at the relevant point is averaged over the 76 days comprising the annual climatologies for November (for 30 days), December (for 31 days) and January (15 days). For temperature, salinity and oxygen variables, monthly climatologies are used above $1500 \mathrm{~m}$ and annual ones below. For nutrients, monthly climatologies are only available and used above $500 \mathrm{~m}$. The distribution of WOA09 climatologies does not extend close to the coasts. Hence, given the proximity of the CARIACO timeseries station to the mainland, ancillary data is not available for this site from WOA09.

\section{Data distribution}

Figure 1 shows the distribution of the sediment-trap deployments compiled in this data set. Data coverage spans from 1982 to 2011, with the largest amount of observations between 1990 and 2010 (Fig. 2). Figure 3 shows a map with the number of data points available on a $5^{\circ} \times 5^{\circ}$ grid. The most abundant contributions to this data set derive from es- tablished time-series stations: BATS $\left(31^{\circ} 40^{\prime} \mathrm{N}, 64^{\circ} 10^{\prime} \mathrm{W}\right)$ 784 data points, $13.2 \%$; CARIACO $\left(10.5^{\circ} \mathrm{N}, 64.4^{\circ} \mathrm{W}\right) 1755$ data points, $29.5 \%$; DYnamique des Flux Atmosphériques en MEDiterranée et leur évolution dans la colonne deau (DYFAMED) $43^{\circ} 25^{\prime} \mathrm{N}, 07^{\circ} 52^{\prime} \mathrm{E}, 401$ data points, $6.7 \%$ of total (Miquel et al., 2011); the Porcupine Abyssal plain (PAP), $49^{\circ} \mathrm{N}, 16^{\circ} 30^{\circ} \mathrm{W}, 366$ data points, $6.2 \%$ of total (Lampitt et al., 2001, 2010); the North Atlantic Bloom Experiment (NABE), from $34^{\circ} \mathrm{N}, 21^{\circ} \mathrm{W}$ to $48^{\circ} \mathrm{N}, 21^{\circ} \mathrm{W}, 170$ data points, $2.9 \%$ of total (Honjo and Manganini, 1993; Martin, 2003a, b, c); and the European Station for Time series in the OCean (ESTOC), $29^{\circ} \mathrm{N}, 15.5^{\circ} \mathrm{W}, 124$ data points, $2.1 \%$ of total (Neuer et al., 1997). Missing in this compilation are data from the Progamme Océan Multidisciplinaire Méso Echelle (POMME, $30-60^{\circ} \mathrm{N}, 0-30^{\circ} \mathrm{W}$ ), which are not yet publicly available. We are also aware of a few more recent data sets from the ESTOC, but these have copyright restrictions (e.g. Neuer et al., 2007).

Observation depths span from 15 down to $5031 \mathrm{~m}$ (Table 2). Tot_Mass, $\mathrm{CaCO}_{3}$ and Terr/Litho exhibit the broadest range of export fluxes $\left(0.0-5585\right.$ and $0.0-4529 \mathrm{mg} \mathrm{m}^{2} \mathrm{~d}^{-1}$, respectively), while PON and PIC exhibit the narrowest range (0.0-57.9 and $\left.0.04-81.4 \mathrm{mg} \mathrm{m}^{2} \mathrm{~d}^{-1}\right)$. The largest number of observations, with higher vertical resolution, have been made within the first $1000 \mathrm{~m}$ of the water column, 


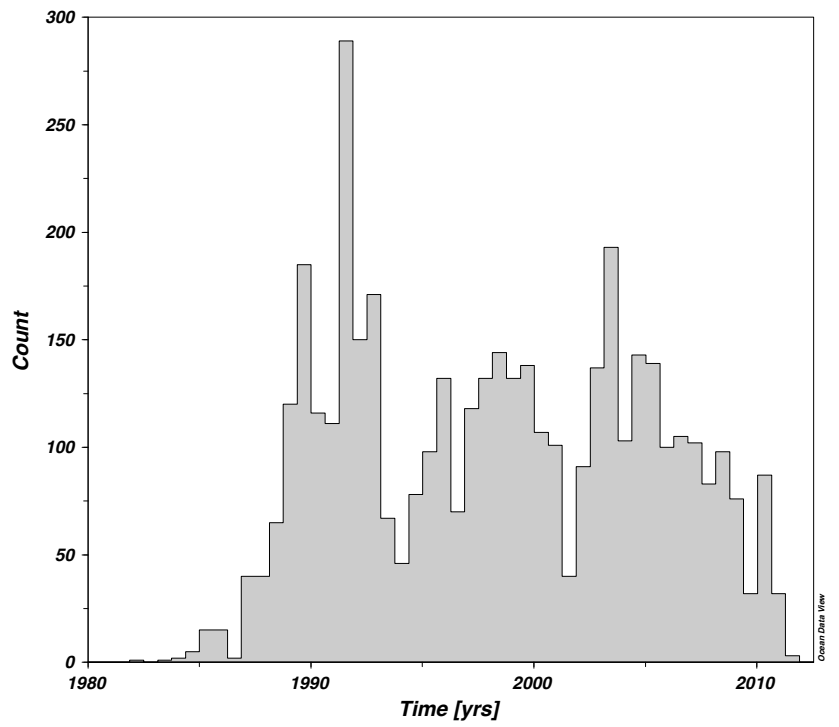

Figure 2. Data-time distribution histogram.

particularly in the upper $500 \mathrm{~m}$ (Fig. 4). At depths greater than $1000 \mathrm{~m}$ a preference for sampling at $3000 \mathrm{~m}$ is apparent in the data. With the exception of the PIC flux and lithogenic/terrigenous flux, which contain the lowest number of data points (Table 2), all other variables of particle export have been sampled at a similar vertical resolution (Fig. 4).

The overall pattern of particle export fluxes show the expected decrease from upper layers to depth as sinking particles decay and dissolve (Fig. 5). This is particularly clear in the Atlantic Ocean and Mediterranean Sea data (red and orange symbols in Fig. 5). POC, $\mathrm{PON}, \mathrm{bSiO}_{2}$ and $\mathrm{CaCO}_{3}$ show a similar vertical structure, with the range of values at a given depth decreasing from surface to depth: from up to $550 \mathrm{mg} \mathrm{m}^{2} \mathrm{~d}^{-1}$ POC and $58 \mathrm{mg} \mathrm{m}^{2} \mathrm{~d}^{-1} \mathrm{PON}$ at $30 \mathrm{~m}$, up to $478 \mathrm{mg}^{2} \mathrm{~d}^{-1} \mathrm{bSiO}_{2}$ at $225 \mathrm{~m}$, and $25000 \mathrm{mg}^{2} \mathrm{~d}^{-1} \mathrm{CaCO}_{3}$ at $152 \mathrm{~m}$, down to $0-6.5 \mathrm{mg}^{2} \mathrm{~d}^{-1} \mathrm{POC}$ at $\sim 5000 \mathrm{~m}$, and up to $1.4 \mathrm{mg}^{2} \mathrm{~d}^{-1} \mathrm{PON}$, up to $27 \mathrm{mg}^{2} \mathrm{~d}^{-1} \mathrm{bSiO}_{2}$ and up to $15 \mathrm{mg}^{2} \mathrm{~d}^{-1} \mathrm{CaCO}_{3}$ at $\sim 4700 \mathrm{~m}$.

In the upper $1000 \mathrm{~m}$, the largest fluxes of POC and PON occur in the Atlantic and the Arctic domains. Within the Arctic domain, the broad range of POC and PON fluxes in the upper $200 \mathrm{~m}$ derive from trap deployments off the northwest coast of Norway $\left(\sim 17^{\circ} \mathrm{E}, \sim 70^{\circ} \mathrm{N}\right)$. The largest fluxes of $\mathrm{bSiO}_{2}$ in the upper $1000 \mathrm{~m}$ are found in the Atlantic and Southern Ocean domains. PIC fluxes are largest in the Atlantic and the Mediterranean Sea. In the Atlantic, PIC data show maximum values at $1400 \mathrm{~m}$, which then decrease at greater depths (Fig. 5). These maximum values at $1400 \mathrm{~m}$, though, derive from trap deployments north of Ireland and may result from the supply of PIC from the shelf or shelf-break front. $\mathrm{CaCO}_{3}$ fluxes are rather comparable among ocean domains, though a larger range is found at about $150 \mathrm{~m}$ in the Atlantic. Terr/Litho fluxes show a broad

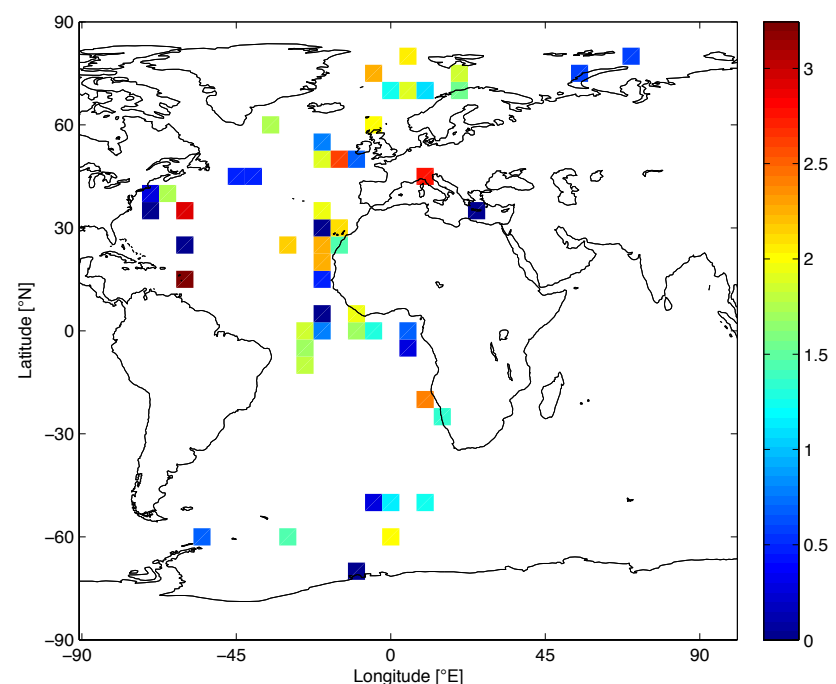

Figure 3. Map showing number of data points on a $5^{\circ} \times 5^{\circ}$ grid ( $\log _{10}$-scale colour-code).

range of values within the upper $1250 \mathrm{~m}$ which reduce substantially at greater depths.

The proportion each export variable makes to total mass flux is shown in Fig. 6. The largest contributions of up to $80 \%$ are provided by the Terr/Litho, $\mathrm{CaCO}_{3}$ and $\mathrm{bSiO}_{2}$ fractions but there is a broad range in the contribution each fraction makes to the total mass flux at all sampled depths and within the four ocean domains. In the case of $\mathrm{CaCO}_{3}$ and Terr/Litho the range in the contribution from these fractions to total mass flux appears to narrow with depth which may reflect the attenuation of other variables with depth rather than any systematic change to Terr/Litho and $\mathrm{CaCO}_{3}$ contributions. The largest contribution (up to $90 \%$ ) made by $\mathrm{bSiO}_{2}$ to total mass flux derive from trap deployments in the Southern Ocean with apparent peaks at depths of 500 and $4500 \mathrm{~m}$; elsewhere the $\mathrm{bSiO}_{2}$ contribution is smaller but nevertheless a major component of the downward particle flux. The contribution made by POC to total mass flux is broadly similar within all four ocean domains and decreases from $\sim 80 \%$ in the upper $500 \mathrm{~m}$ to $<20 \%$ at $5000 \mathrm{~m}$ revealing a marked attenuation with depth. Both PON and PIC typically contribute $<20 \%$ to total mass flux, but, whilst the contribution from PIC remains fairly constant with depth, there is vertical attenuation of PON with depth such that at depths $>500 \mathrm{~m}$ the PON contribution is $<10 \%$.

\section{Conclusions}

We have assembled a data set of over 5900 data points of particle flux across the wider Atlantic Ocean and adjacent seas, which will be invaluable in determining seasonal and geographical variability in the biological carbon pump. Our initial examination of this data set already indicates important 

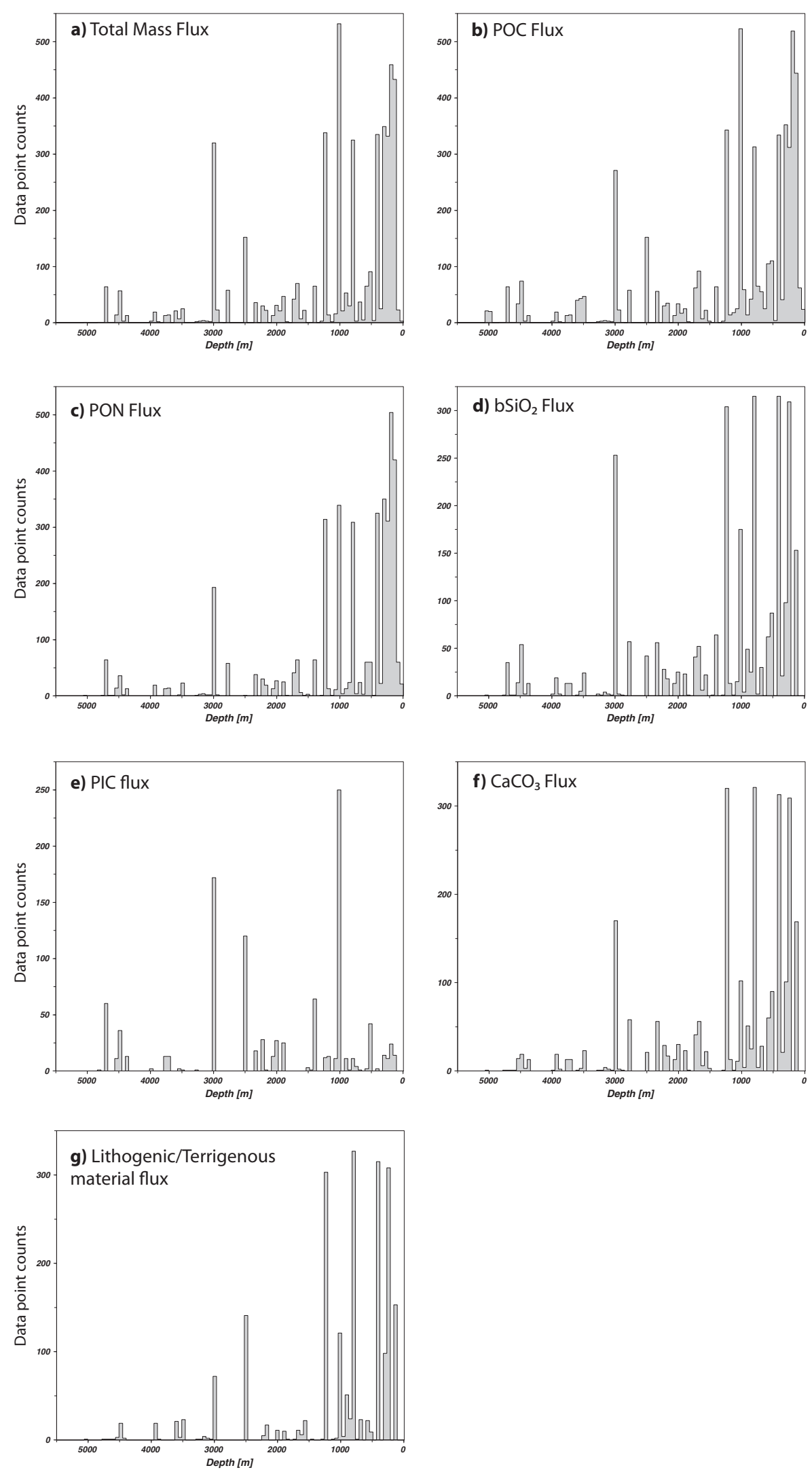

Figure 4. Data points available per depth; (a) total mass flux, (b) $\mathrm{POC}$ flux, (c) $\mathrm{PON}$ flux, (d) $\mathrm{bSiO}_{2}$ flux, (e) $\mathrm{PIC}$ flux, (f) $\mathrm{CaCO}_{3}$ flux, and (g) lithogenic/terrigenous material flux. 

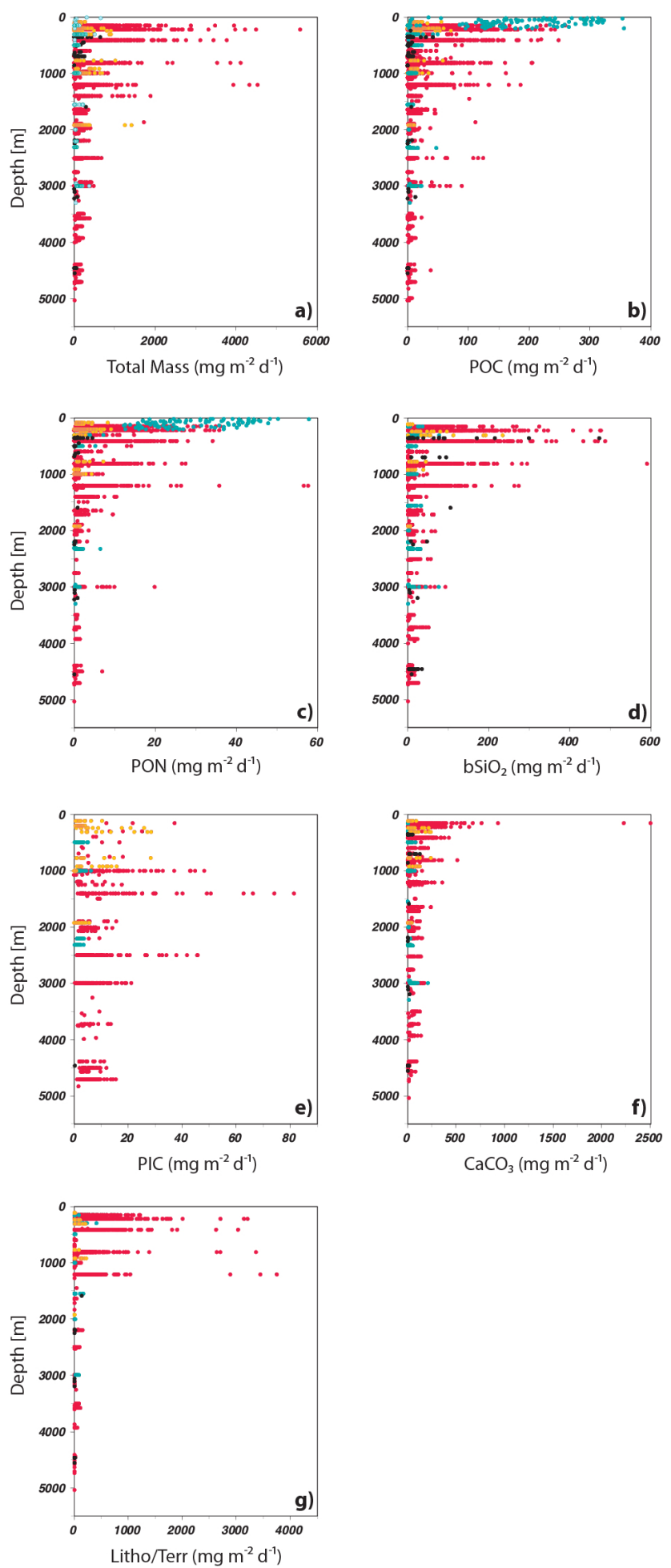

Figure 5. Downward fluxes plotted against depth; (a) total mass, (b) $\mathrm{POC}$, (c) $\mathrm{PON}$, (d) $\mathrm{bSiO}_{2}$, (e) $\mathrm{PIC}$, (f) $\mathrm{CaCO}_{3}$, and (g) Litho/Terr. Data points are colour-coded per ocean domain: Atlantic (red dots), Mediterranean (orange dots), Arctic (blue dots), and Southern Ocean (black dots). differences in the flux estimates between ocean domains and in the contribution particular flux variables make to the total mass flux, which may in turn indicate important differences in the strength of the BCP due to local environmentaland ecosystem-level forcing. Exploring the reasons for such differences remains a major scientific and societal problem particularly given projected changes to the future ocean and this data set will help in this endeavour. This data set has been submitted to the data repository PANGAEA ${ }^{\circledR}$ (http: //www.pangaea.de), where it has been made available under doi:10.1594/PANGAEA.807946.

\section{List of compiled data sets}

Here we list all individual data sets. PANGAEA ${ }^{\circledR}$ digital object identifiers are also given.

- Antia, Avan N (2003): Particle fluxes of L2-B-92_trap. doi:10.1594/PANGAEA.92747

- Antia, Avan N (2003): Particle fluxes of OMEX2_trap. doi:10.1594/PANGAEA.92749

- Antia, Avan N (2003): Particle fluxes of OMEX3_trap. doi:10.1594/PANGAEA.92748

- Antia, Avan N (2003): Particle fluxes of SEEP-7_trap. doi:10.1594/PANGAEA.92746

- Antia, Avan N (2003): Particle Flux of SEEP-10_trap. doi:10.1594/PANGAEA.92745

- Bahr, Fred; Bates, Nicolas R (2013): Total flux, particulate carbon and nitrogen from surface-tethered sediment traps at time series station BATS in 1988 and 1989. doi:10.1594/PANGAEA.805543

- Bahr, Fred; Bates, Nicolas R (2013): Total flux, particulate carbon and nitrogen from surface-tethered sediment traps at time series station BATS in 1990. doi:10.1594/PANGAEA.805545

- Bahr, Fred; Bates, Nicolas R (2013): Total flux, particulate carbon and nitrogen from surface-tethered sediment traps at time series station BATS in 1991. doi:10.1594/PANGAEA.805546

- Bahr, Fred; Bates, Nicolas R (2013): Total flux, particulate carbon and nitrogen from surface-tethered sediment traps at time series station BATS in 1992. 

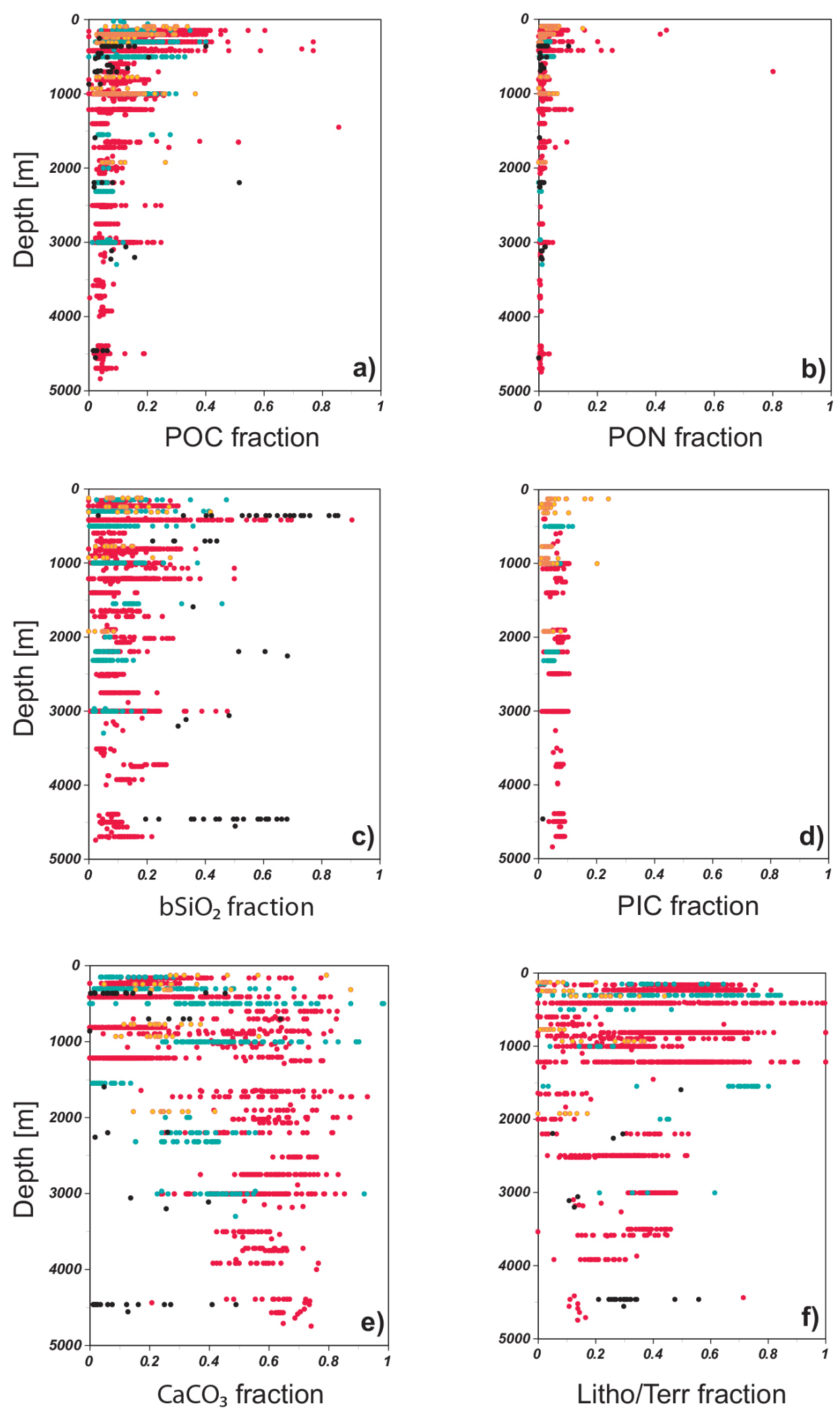

Figure 6. Fraction of POC, PON, and $\mathrm{bSiO}_{2}, \mathrm{PIC}, \mathrm{CaCO}_{3}$ and Litho/Terr downward fluxes relative to Tot_Mass flux. Data points are colourcoded per ocean domain: Atlantic (red dots), Mediterranean (orange dots), Arctic (blue dots), and Southern Ocean (black dots). Few outliers (fraction $>1$ ) were excluded from the graphs. 
doi:10.1594/PANGAEA.805547

- Bahr, Fred; Bates, Nicolas R (2013): Total flux, particulate carbon and nitrogen from surface-tethered sediment traps at time series station BATS in 1993. doi:10.1594/PANGAEA. 805548

- Bahr, Fred; Bates, Nicolas R (2013): Total flux, particulate carbon and nitrogen from surface-tethered sediment traps at time series station BATS in 1994. doi:10.1594/PANGAEA.805549

- Bahr, Fred; Bates, Nicolas R (2013): Total flux, particulate carbon and nitrogen from surface-tethered sediment traps at time series station BATS in 1995. doi:10.1594/PANGAEA. 805550

- Bahr, Fred; Bates, Nicolas R (2013): Total flux, particulate carbon and nitrogen from surface-tethered sediment traps at time series station BATS in 1996. doi:10.1594/PANGAEA.805551

- Bahr, Fred; Bates, Nicolas R (2013): Total flux, particulate carbon and nitrogen from surface-tethered sediment traps at time series station BATS in 1997. doi:10.1594/PANGAEA.805552

- Bahr, Fred; Bates, Nicolas R (2013): Total flux, particulate carbon and nitrogen from surface-tethered sediment traps at time series station BATS in 1998. doi:10.1594/PANGAEA.805553

- Bahr, Fred; Bates, Nicolas R (2013): Total flux, particulate carbon and nitrogen from surface-tethered sediment traps at time series station BATS in 1999. doi:10.1594/PANGAEA.805554

- Bahr, Fred; Bates, Nicolas R (2013): Total flux, particulate carbon and nitrogen from surface-tethered sediment traps at time series station BATS in 2000. doi:10.1594/PANGAEA.805555

- Bahr, Fred; Bates, Nicolas R (2013): Total flux, particulate carbon and nitrogen from surface-tethered sediment traps at time series station BATS in 2001. doi:10.1594/PANGAEA.805556
- Bahr, Fred; Bates, Nicolas R (2013): Total flux, particulate carbon and nitrogen from surface-tethered sediment traps at time series station BATS in 2002. doi:10.1594/PANGAEA.805557

- Bahr, Fred; Bates, Nicolas R (2013): Total flux, particulate carbon and nitrogen from surface-tethered sediment traps at time series station BATS in 2003. doi:10.1594/PANGAEA.805559

- Bahr, Fred; Bates, Nicolas R (2013): Total flux, particulate carbon and nitrogen from surface-tethered sediment traps at time series station BATS in 2004. doi:10.1594/PANGAEA.805560

- Bahr, Fred; Bates, Nicolas R (2013): Total flux, particulate carbon and nitrogen from surface-tethered sediment traps at time series station BATS in 2005. doi:10.1594/PANGAEA.805561

- Bahr, Fred; Bates, Nicolas R (2013): Total flux, particulate carbon and nitrogen from surface-tethered sediment traps at time series station BATS in 2006. doi:10.1594/PANGAEA.805562

- Bahr, Fred; Bates, Nicolas R (2013): Total flux, particulate carbon and nitrogen from surface-tethered sediment traps at time series station BATS in 2007. doi:10.1594/PANGAEA.805563

- Bahr, Fred; Bates, Nicolas R (2013): Total flux, particulate carbon and nitrogen from surface-tethered sediment traps at time series station BATS in 2008. doi:10.1594/PANGAEA.805564

- Bahr, Fred; Bates, Nicolas R (2013): Total flux, particulate carbon and nitrogen from surface-tethered sediment traps at time series station BATS in 2009. doi:10.1594/PANGAEA.805565

- Bahr, Fred; Bates, Nicolas R (2013): Total flux, particulate carbon and nitrogen from surface-tethered sediment traps at time series station BATS in 2010. doi:10.1594/PANGAEA.805566

- Bahr, Fred; Bates, Nicolas R (2013): Total flux, particulate carbon and nitrogen from surface-tethered sediment traps at time series station BATS in 2011. doi:10.1594/PANGAEA.805567 
- Bauerfeind, Eduard; Nöthig, Eva-Maria (2011): Biogenic particle flux at AWI HAUSGARTEN from mooring FEVI3 at $2400 \mathrm{~m}$. Alfred Wegener Institute, Helmholtz Center for Polar and Marine Research, Bremerhaven, doi:10.1594/PANGAEA.757777

- Bauerfeind, Eduard; Nöthig, Eva-Maria; Beszczynska, Agnieszka; Fahl, Kirsten; Kaleschke, Lars; Kreker, Kathrin; Klages, Michael; Soltwedel, Thomas; Lorenzen, Christiane; Wegner, Jan (2009): Biogenic particle flux at AWI HAUSGARTEN from mooring FEVI1. doi:10.1594/PANGAEA.714840

- Bauerfeind, Eduard; Nöthig, Eva-Maria; Beszczynska, Agnieszka; Fahl, Kirsten; Kaleschke, Lars; Kreker, Kathrin; Klages, Michael; Soltwedel, Thomas; Lorenzen, Christiane; Wegner, Jan (2009): Biogenic particle flux at AWI HAUSGARTEN from mooring FEVI2. doi:10.1594/PANGAEA.714841

- Bauerfeind, Eduard; Nöthig, Eva-Maria; Beszczynska, Agnieszka; Fahl, Kirsten; Kaleschke, Lars; Kreker, Kathrin; Klages, Michael; Soltwedel, Thomas; Lorenzen, Christiane; Wegner, Jan (2009): Biogenic particle flux at AWI HAUSGARTEN from mooring FEVI3 at 300 m. doi:10.1594/PANGAEA.714842

- Bauerfeind, Eduard; Nöthig, Eva-Maria; Beszczynska, Agnieszka; Fahl, Kirsten; Kaleschke, Lars; Kreker, Kathrin; Klages, Michael; Soltwedel, Thomas; Lorenzen, Christiane; Wegner, Jan (2009): Biogenic particle flux at AWI HAUSGARTEN from mooring FEVI4. doi:10.1594/PANGAEA.714843

- Bauerfeind, Eduard; Nöthig, Eva-Maria; Beszczynska, Agnieszka; Fahl, Kirsten; Kaleschke, Lars; Kreker, Kathrin; Klages, Michael; Soltwedel, Thomas; Lorenzen, Christiane; Wegner, Jan (2009): Biogenic particle flux at AWI HAUSGARTEN from mooring FEVI7. doi:10.1594/PANGAEA.714844

- Bory, A; Jeandel, Catherine; Leblond, Nathalie; Vangriesheim, Annick; Khripounoff, Alexis; Beaufort, Luc; Rabouille, Christophe; Nicolas, E; Tachikawa, Kazuyo; Etcheber, Henri; Buat-Menard, P (2012): Downward particle fluxes at the oligotrophic and mesotrophic site of the EUMELI program. doi:10.1594/PANGAEA.793296
- Dymond, Jack R; Lyle, Mitchell W (2003): Particle fluxes of HAP-4_trap. doi:10.1594/PANGAEA.92843

- Dymond, Jack R; Lyle, Mitchell W (2003): Particle fluxes of NAP_trap. doi:10.1594/PANGAEA.92842

- Fahl, Kirsten; Nöthig, Eva-Maria (2007): Lithogenic and biogenic annual particle fluxes on the Lomonosov Ridge of trap LOMO-2. doi:10.1594/PANGAEA.586842

- Fahl, Kirsten; Nöthig, Eva-Maria (2007): Lithogenic and biogenic particle fluxes on the Lomonosov Ridge of trap LOMO-2. doi:10.1594/PANGAEA.586835

- Fischer, Gerhard (2003): Flux data of trap WR2. doi:10.1594/PANGAEA.89288

- Fischer, Gerhard (2003): Flux data of trap WR3. doi:10.1594/PANGAEA.89289

- Fischer, Gerhard (2003): Flux data of trap WR4. doi:10.1594/PANGAEA.89290

- Fischer, Gerhard (2005): Particle fluxes for the sampling interval, various ratios and major nutrients at the Atlantic/Southern Ocean trapping sites. doi:10.1594/PANGAEA.269660

- Fischer, Gerhard (2003): Particle fluxes of trap NU2. doi:10.1594/PANGAEA. 115858

- Fischer, Gerhard; Gersonde, Rainer; Wefer, Gerold (2002): (Table 4) Annual fluxes, percentages of total mass and most important elemental ratios at the PF and BO sites. doi:10.1594/PANGAEA.760872

- Fischer, Gerhard; Ratmeyer, Volker; Wefer, Gerold (2012): Total organic carbon fluxes $(<1 \mathrm{~mm}$ size fraction), and export fluxes to a depth of $1000 \mathrm{~m}$ in the Atlantic and Southern Ocean. doi:10.1594/PANGAEA. 802815

- Goutx, Madeleine; Momzikoff, André; Striby, L; Andersen, Valérie; Marty, Jean-Claude; Vescovali, Isabelle (2000): Fluxes of particulate organic carbon and nitrogen at DYNAPROC station. doi:10.1594/PANGAEA. 185223 
- Helmke, Peer; Romero, Oscar E; Fischer, Gerhard (2005): Sampling intervals, fluxes, percentages of total flux, organic carbon and lithogen for sediment trap CB9. doi:10.1594/PANGAEA.319950

- Honjo, Susumu; Manganini, Steven J (2003): Annual Particle fluxes of NABE-N34_trap. doi:10.1594/PANGAEA.93385

- Honjo, Susumu; Manganini, Steven J (2003): Annual Particle fluxes of NABE-N48_trap. doi:10.1594/PANGAEA.93386

- Honjo, Susumu; Manganini, Steven J (2003): Biogenic particle flux of trap NABE-N34.1. doi:10.1594/PANGAEA.111884

- Honjo, Susumu; Manganini, Steven J (2003): Biogenic particle flux of trap NABE-N34.2. doi:10.1594/PANGAEA.111885

- Honjo, Susumu; Manganini, Steven J (2003): Biogenic particle flux of trap NABE-N48.1. doi:10.1594/PANGAEA.111886

- Honjo, Susumu; Manganini, Steven J (2003): Biogenic particle flux of trap NABE-N48.2. doi:10.1594/PANGAEA.111887

- Hwang, Jeomshik; Manganini, Steven J; Montluon, D; Eglinton, Timothy I (2012): Biogeochemical properties of sinking particles intercepted at three depths on the NW Atlantic margin. doi:10.1594/PANGAEA.793329

- Irwin, Brian (2002): POC, PON, chlorophyll, phaeophytin of BAF89/3_FTRAP1. doi:10.1594/PANGAEA.70440

- Irwin, Brian (2002): POC, PON, chlorophyll, phaeophytin of BAF89/3_FTRAP2. doi:10.1594/PANGAEA.70446

- Iversen, Morten Hvitfeldt; Nowald, Nicolas; Ploug, Helle; Jackson, George A; Fischer, Gerhard (2010): (Table 2) Total mass and organic carbon fluxes shown for each deployment. doi:10.1594/PANGAEA.745509
- Jickells, Timothy D (2003): Particle fluxes of $19^{\circ} \mathrm{N} 20^{\circ}$ W_trap. doi:10.1594/PANGAEA.93417

- Jickells, Timothy D (2003): Particle fluxes of $24^{\circ} \mathrm{N} 23^{\circ}$ W_trap. doi:10.1594/PANGAEA.93418

- Jickells, Timothy D (2003): Particle fluxes of $28^{\circ} \mathrm{N} 22^{\circ}$ W_trap. doi:10.1594/PANGAEA.93419

- Jickells, Timothy D (2003): Particle fluxes of Parflux7G_trap.doi:10.1594/PANGAEA.93420

- Jonkers, Lukas; Brummer, Geert-Jan A; Peeters, Frank J C; van Aken, Hendrik M; de Jong, M Femke (2010): Shell flux and oxygen isotope data of North Atlantic foraminifera. doi:10.1594/PANGAEA.753860

- Lampitt, Richard S; Antia, Avan N; Fischer, Gerhard (2006): Particle fluxes from sediment trap CB1. doi:10.1594/PANGAEA.357362

- Lampitt, Richard S; Antia, Avan N; Fischer, Gerhard (2006): Particle fluxes from sediment trap CB2. doi:10.1594/PANGAEA.357363

- Lampitt, Richard S; Antia, Avan N; Fischer, Gerhard (2006): Particle fluxes from sediment trap GBN3. doi:10.1594/PANGAEA.357371

- Lampitt, Richard S; Antia, Avan N; Fischer, Gerhard (2006): Particle fluxes from sediment trap GBZ4. doi:10.1594/PANGAEA.357373

- Lampitt, Richard S; Antia, Avan N; Fischer, Gerhard (2006): Particle fluxes from sediment trap WR1. doi:10.1594/PANGAEA.357381

- Lampitt, Richard S; Antia, Avan N; Fischer, Gerhard (2006): Particle fluxes from sediment trap WR2. doi:10.1594/PANGAEA.357382

- Lampitt, Richard S; Antia, Avan N; Fischer, Gerhard (2006): Particle fluxes from sediment trap WR3. doi:10.1594/PANGAEA.357383 
- Lampitt, Richard S; Antia, Avan N; Fischer, Gerhard (2006): Particle fluxes from sediment trap WR4. doi:10.1594/PANGAEA.357384

- Lampitt, Richard S; Bett, Brian J; Kiriakoulakis, Kostas; Popova, E E; Ragueneau, Olivier; Vangriesheim, Annick; Wolff, George A (2001): Particle flux from sediment trap PAP-I. doi:10.1594/PANGAEA.108311

- Lampitt, Richard S; Bett, Brian J; Kiriakoulakis, Kostas; Popova, E E; Ragueneau, Olivier; Vangriesheim, Annick; Wolff, George A (2001): Particle flux from sediment trap PAP-III. doi:10.1594/PANGAEA.108312

- Lampitt, Richard S; Bett, Brian J; Kiriakoulakis, Kostas; Popova, E E; Ragueneau, Olivier; Vangriesheim, Annick; Wolff, George A (2001): Particle flux from sediment trap PAP-V. doi:10.1594/PANGAEA.108313

- Lampitt, Richard S; Bett, Brian J; Kiriakoulakis, Kostas; Popova, E E; Ragueneau, Olivier; Vangriesheim, Annick; Wolff, George A (2001): Particle flux from sediment trap PAP-XIX. doi:10.1594/PANGAEA.108314

- Lampitt, Richard S; Bett, Brian J; Kiriakoulakis, Kostas; Popova, E E; Ragueneau, Olivier; Vangriesheim, Annick; Wolff, George A (2001): Particle flux from sediment trap PAP-XV. doi:10.1594/PANGAEA.108315

- Lampitt, Richard S; Bett, Brian J; Kiriakoulakis, Kostas; Popova, E E; Ragueneau, Olivier; Vangriesheim, Annick; Wolff, George A (2001): Particle flux from sediment trap PAP-XVIII. doi:10.1594/PANGAEA.108316

- Lampitt, Richard S; Bett, Brian J; Kiriakoulakis, Kostas; Popova, E E; Ragueneau, Olivier; Vangriesheim, Annick; Wolff, George A (2001): Particle flux from sediment trap PAP-XX. doi:10.1594/PANGAEA.108317

- Lampitt, Richard S; Bett, Brian J; Kiriakoulakis, Kostas; Popova, E E; Ragueneau, Olivier; Vangriesheim, Annick; Wolff, George A (2001): Particle flux from sediment trap PAP-XXIIIa.
doi:10.1594/PANGAEA.108318

- Lampitt, Richard S; Bett, Brian J; Kiriakoulakis, Kostas; Popova, E E; Ragueneau, Olivier; Vangriesheim, Annick; Wolff, George A (2001): Particle flux from sediment trap PAP-XXV. doi:10.1594/PANGAEA.108319

- Lampitt, Richard S; Salters, Vincent JM; de Cuevas, Beverly; Hartman, S; Larkin, Kate E; Pebody, C A (2010): Particle flux from sediment trap PAP-XXVI. doi:10.1594/PANGAEA.794531

- Lampitt, Richard S; Salters, Vincent JM; de Cuevas, Beverly; Hartman, S; Larkin, Kate E; Pebody, C A (2010): Particle flux from sediment trap PAP-XXVII. doi:10.1594/PANGAEA.794532

- Lampitt, Richard S; Salters, Vincent JM; de Cuevas, Beverly; Hartman, S; Larkin, Kate E; Pebody, C A (2010): Particle flux from sediment trap PAP-XXVIII. doi:10.1594/PANGAEA.794533

- Lampitt, Richard S; Salters, Vincent JM; de Cuevas, Beverly; Hartman, S; Larkin, Kate E; Pebody, C A (2010): Particle flux from sediment trap PAP-XXXI. doi:10.1594/PANGAEA.794534

- Lee, Cindy; Peterson, Michael L; Wakeham, Stuart G; Armstrong, Robert A; Cochran, J Kirk; Fukai, R; Fowler, Scott W; Hirschberg, David; Beck, Aaron; Xue, Jianhong (2013): Sediment Trap Data in the northwest Mediterranean Sea from the MedFlux project (2003 2005). doi:10.1594/PANGAEA.806963

- Martin, John (2003): Particle interceptor data of sediment trap AT_II-119/4_Trap_A. doi:10.1594/PANGAEA.112905

- Martin, John (2003): Particle interceptor data of sediment trap AT_II-119/4_Trap_B. doi:10.1594/PANGAEA.112906

- Martin, John (2003): Particle interceptor data of sediment trap AT_II-119/5_Trap_C. doi:10.1594/PANGAEA.112907 
- Miquel, Juan-Carlos (2004): Particulate flux of carbon at DYNAPROC station. doi:10.1594/PANGAEA.185222

- Miquel, Juan-Carlos; Marty, Jean-Claude (2004): Downward flux of particles and carbon at trap DYF1. doi:10.1594/PANGAEA.183686

- Miquel, Juan-Carlos; Marty, Jean-Claude (2004): Downward flux of particles and carbon at trap DYF10. doi:10.1594/PANGAEA.183687

- Miquel, Juan-Carlos; Marty, Jean-Claude (2004): Downward flux of particles and carbon at trap DYF11. doi:10.1594/PANGAEA.183688

- Miquel, Juan-Carlos; Marty, Jean-Claude (2004): Downward flux of particles and carbon at trap DYF12. doi:10.1594/PANGAEA.183689

- Miquel, Juan-Carlos; Marty, Jean-Claude (2004): Downward flux of particles and carbon at trap DYF13. doi:10.1594/PANGAEA.183690

- Miquel, Juan-Carlos; Marty, Jean-Claude (2004): Downward flux of particles and carbon at trap DYF14. doi:10.1594/PANGAEA.183691

- Miquel, Juan-Carlos; Marty, Jean-Claude (2004): Downward flux of particles and carbon at trap DYF16. doi:10.1594/PANGAEA.183692

- Miquel, Juan-Carlos; Marty, Jean-Claude (2004): Downward flux of particles and carbon at trap DYF17. doi:10.1594/PANGAEA.183693

- Miquel, Juan-Carlos; Marty, Jean-Claude (2004): Downward flux of particles and carbon at trap DYF18. doi:10.1594/PANGAEA.183694

- Miquel, Juan-Carlos; Marty, Jean-Claude (2004): Downward flux of particles and carbon at trap DYF19. doi:10.1594/PANGAEA.183695

- Miquel, Juan-Carlos; Marty, Jean-Claude (2004): Downward flux of particles and carbon at trap DYF20. doi:10.1594/PANGAEA.183698
- Miquel, Juan-Carlos; Marty, Jean-Claude (2004): Downward flux of particles and carbon at trap DYF21. doi:10.1594/PANGAEA.183699

- Miquel, Juan-Carlos; Marty, Jean-Claude (2004): Downward flux of particles and carbon at trap DYF23. doi:10.1594/PANGAEA. 183700

- Miquel, Juan-Carlos; Marty, Jean-Claude (2004): Downward flux of particles and carbon at trap DYF24. doi:10.1594/PANGAEA.183701

- Miquel, Juan-Carlos; Marty, Jean-Claude (2004): Downward flux of particles and carbon at trap DYF25. doi:10.1594/PANGAEA.183702

- Miquel, Juan-Carlos; Marty, Jean-Claude (2004): Downward flux of particles and carbon at trap DYF26. doi:10.1594/PANGAEA.183703

- Miquel, Juan-Carlos; Marty, Jean-Claude (2004): Downward flux of particles and carbon at trap DYF27. doi:10.1594/PANGAEA.183704

- Miquel, Juan-Carlos; Marty, Jean-Claude (2004): Downward flux of particles and carbon at trap DYF2Calvi. doi:10.1594/PANGAEA.183696

- Miquel, Juan-Carlos; Marty, Jean-Claude (2004): Downward flux of particles and carbon at trap DYF3. doi:10.1594/PANGAEA.183706

- Miquel, Juan-Carlos; Marty, Jean-Claude (2004): Downward flux of particles and carbon at trap DYF3Calvi. doi:10.1594/PANGAEA.183705

- Miquel, Juan-Carlos; Marty, Jean-Claude (2004): Downward flux of particles and carbon at trap DYF4. doi:10.1594/PANGAEA.183708

- Miquel, Juan-Carlos; Marty, Jean-Claude (2004): Downward flux of particles and carbon at trap DYF5. doi:10.1594/PANGAEA. 183710

- Miquel, Juan-Carlos; Marty, Jean-Claude (2004): Downward flux of particles and carbon at trap DYF5Calvi. doi:10.1594/PANGAEA.183709 
- Miquel, Juan-Carlos; Marty, Jean-Claude (2004): Downward flux of particles and carbon at trap DYF6. doi:10.1594/PANGAEA.183712

- Miquel, Juan-Carlos; Marty, Jean-Claude (2004): Downward flux of particles and carbon at trap DYF6Calvi. doi:10.1594/PANGAEA.183711

- Miquel, Juan-Carlos; Marty, Jean-Claude (2004): Downward flux of particles and carbon at trap DYF7. doi:10.1594/PANGAEA.183714

- Miquel, Juan-Carlos; Marty, Jean-Claude (2004): Downward flux of particles and carbon at trap DYF7Calvi. doi:10.1594/PANGAEA.183713

- Miquel, Juan-Carlos; Marty, Jean-Claude (2004): Downward flux of particles and carbon at trap DYF8. doi:10.1594/PANGAEA.183715

- Miquel, Juan-Carlos; Marty, Jean-Claude (2004): Downward flux of particles and carbon at trap DYF9. doi:10.1594/PANGAEA.183716

- Neuer, Susanne; Ratmeyer, Volker; Davenport, Robert; Fischer, Gerhard; Wefer, Gerold (1997): Flux data from trap CI1. doi:10.1594/PANGAEA.57966

- Neuer, Susanne; Ratmeyer, Volker; Davenport, Robert; Fischer, Gerhard; Wefer, Gerold (1997): Flux data from trap CI2. doi:10.1594/PANGAEA.725938

- Neuer, Susanne; Ratmeyer, Volker; Davenport, Robert; Fischer, Gerhard; Wefer, Gerold (1997): Flux data from trap CI3. doi:10.1594/PANGAEA.725939

- Neuer, Susanne; Ratmeyer, Volker; Davenport, Robert; Fischer, Gerhard; Wefer, Gerold (1997): Flux data from trap CI4. doi:10.1594/PANGAEA.725940

- NGOFS; Tande, Kurt (2003): Particle flux of drift station JM9-1. doi:10.1594/PANGAEA.106530

- OMEX Project Members; Wassmann, Paul (2004): Fluxes of trap JM10_DRIFT2. doi:10.1594/PANGAEA.218086
- OMEX Project Members; Wassmann, Paul (2004): Fluxes of trap JM11_DRIFT1. doi:10.1594/PANGAEA.218087

- OMEX Project Members; Wassmann, Paul (2004): Fluxes of trap JM3_DRIFT1. doi:10.1594/PANGAEA.218089

- OMEX Project Members; Wassmann, Paul (2004): Fluxes of trap JM4_DRIFT1. doi:10.1594/PANGAEA.218090

- OMEX Project Members; Wassmann, Paul (2004): Fluxes of trap JM5_DRIFT1. doi:10.1594/PANGAEA.218091

- OMEX Project Members; Wassmann, Paul (2004): Fluxes of trap JM6_DRIFT1. doi:10.1594/PANGAEA.218092

- OMEX Project Members; Wassmann, Paul (2004): Fluxes of trap JM7_DRIFT1. doi:10.1594/PANGAEA.218093

- OMEX Project Members; Wassmann, Paul (2004): Fluxes of trap JM9_DRIFT1. doi:10.1594/PANGAEA.218094

- Peinert, Rolf; Antia, Avan N; Bauerfeind, Eduard; von Bodungen, Bodo; Haupt, Olaf; Krumbholz, Marita; Peeked, Ilka; Ramseier, René O; Voß, Maren; Zeitzschel, Bernt (2005): Annual fluxes as measured by moored traps in different years for the Atlantic Province. doi:10.1594/PANGAEA.231354

- Peinert, Rolf; Antia, Avan N; Bauerfeind, Eduard; von Bodungen, Bodo; Haupt, Olaf; Krumbholz, Marita; Peeken, Ilka; Ramseier, René O; Voß, Maren; Zeitzschel, Bernt (2005): Annual fluxes as measured by moored traps in different years for the Polar Province. doi:10.1594/PANGAEA.231353

- Raab, Alexandra; von Bodungen, Bodo (2003): Monthly mean flux values at mooring station VP (Vring Plateau). doi:10.1594/PANGAEA.106809

- Raab, Alexandra; von Bodungen, Bodo (2003): Monthly mean flux values at moring station NB (Lofoten Basin). doi:10.1594/PANGAEA.106810 
- Shevchenko, Vladimir P (2000): tab1+2. doi:10.1594/PANGAEA.56212

- Tett, Paul (2005): Flux values of different LOIS-Trap Sites. doi:10.1594/PANGAEA.56170

- Thomsen, C; von Bodungen, Bodo (2001): tab 3.1.1+2 Vertical particle flux and alkenones in mooring NB6. doi:10.1594/PANGAEA.60035

- Thomsen, C; von Bodungen, Bodo (2001): tab 3.2.1+2 Vertical particle flux and alkenones in mooring OG4. doi:10.1594/PANGAEA.60034

- Thunell, Robert C; Tappa, Eric (2013): Sediment Trap Data from the CARIACO Ocean Time Series (1995-2010). doi:10.1594/PANGAEA.805397

- von Bodungen, Bodo; Antia, Avan N; Bauerfeind, Eduard; Haupt, Olaf; Koeve, Wolfgang; Machado, E; Peeken, Ilka; Peinert, Rolf; Reitmeier, Sven; Thomsen, C; Voß, Maren; Wunsch, M; Zeller, Ute; Zeitzschel, Bernt (1995): Flux data in the Greenland Basin from sediment trap OG4. doi:10.1594/PANGAEA.56177

- von Bodungen, Bodo; Antia, Avan N; Bauerfeind, Eduard; Haupt, Olaf; Koeve, Wolfgang; Machado, E; Peeken, Ilka; Peinert, Rolf; Reitmeier, Sven; Thomsen, C; Voß, Maren; Wunsch, M; Zeller, Ute; Zeitzschel, Bernt (1995): Particle and nutrient flux data from mooring OG5 in the Greenland Basin. doi:10.1594/PANGAEA.72222

- Waniek, Joanna J; Schulz-Bull, Detlef; Kuss, Joachim; Blanz, Thomas (2005): Deep ocean particle flux $(>1000 \mathrm{~m})$ and composition of particles collected by sediment traps at various sites in the northeast Atlantic (open ocean only) compiled from different sources. doi:10.1594/PANGAEA.802282

- Waniek, Joanna J; Schulz-Bull, Detlef; Kuss, Joachim; Blanz, Thomas (2005): Interannual comparison of deep partical fluxes in the northeast Atlantic. doi:10.1594/PANGAEA.802211

- Wefer, Gerold (2003): Particle fluxes of KG2_trap. doi:10.1594/PANGAEA.93499
- Wefer, Gerold (2003): Particle fluxes of WS2_trap. doi:10.1594/PANGAEA.93498

- Wefer, Gerold; Fischer, Gerhard (1991): (Table 2) Estimates of annual flux data in the South Atlantic. doi:10.1594/PANGAEA.92454

- Wefer, Gerold; Fischer, Gerhard (1991): (Table 2a) Flux data of total mass and individual biogenic components for trap WS3. doi:10.1594/PANGAEA.89396

- Wefer, Gerold; Fischer, Gerhard (1991): (Table 2b) Flux data of total mass and individual biogenic components for trap WS4. doi:10.1594/PANGAEA.89397

- Wefer, Gerold; Fischer, Gerhard (1991): (Table 2c) Flux data of total mass and individual biogenic components for trap Polar_Front_1. doi:10.1594/PANGAEA.734156

- Wefer, Gerold; Fischer, Gerhard (2003): Particle fluxes of CB1_trap. doi:10.1594/PANGAEA.93490

- Wefer, Gerold; Fischer, Gerhard (2003): Particle fluxes of CB2_trap. doi:10.1594/PANGAEA.93491

- Wefer, Gerold; Fischer, Gerhard (2003): Particle fluxes of CB4_trap. doi:10.1594/PANGAEA.93492

- Wefer, Gerold; Fischer, Gerhard (2003): Particle fluxes of GBN6_trap. doi:10.1594/PANGAEA.93489

- Wefer, Gerold; Fischer, Gerhard (2003): Particle fluxes of GBZ4_trap. doi:10.1594/PANGAEA.93488

- Žarić, Snježana (2005): Planktic foraminiferal flux of sediment trap CB1_trap. doi:10.1594/PANGAEA.264495

- Žarić, Snježana (2005): Planktic foraminiferal flux of sediment trap CB2_trap. doi:10.1594/PANGAEA.264496

- Žarić, Snježana (2005): Planktic foraminiferal flux of sediment trap CB3_trap. doi:10.1594/PANGAEA.264497 
- Žarić, Snježana (2005): Planktic foraminiferal flux of sediment trap CB4_trap, lower. doi:10.1594/PANGAEA.264645

- Žarić, Snježana (2005): Planktic foraminiferal flux of sediment trap CB4_trap, upper. doi:10.1594/PANGAEA.264644

- Žarić, Snježana (2005): Planktic foraminiferal flux of sediment trap CB5_trap. doi:10.1594/PANGAEA.264499

- Žarić, Snježana (2005): Planktic foraminiferal flux of sediment trap EA1_trap. doi:10.1594/PANGAEA.264504

- Žarić, Snježana (2005): Planktic foraminiferal flux of sediment trap EA2_trap. doi:10.1594/PANGAEA.264505

- Žarić, Snježana (2005): Planktic foraminiferal flux of sediment trap EA3_trap. doi:10.1594/PANGAEA.264506

- Žarić, Snježana (2005): Planktic foraminiferal flux of sediment trap EA4_trap. doi:10.1594/PANGAEA.264507

- Žarić, Snježana (2005): Planktic foraminiferal flux of sediment trap WA1_trap, $1232 \mathrm{~m}$ trap depth. Department of Geosciences, Bremen University, doi:10.1594/PANGAEA.264697

- Žarić, Snježana (2005): Planktic foraminiferal flux of sediment trap WA1_trap, $4991 \mathrm{~m}$ trap depth. Department of Geosciences, Bremen University, doi:10.1594/PANGAEA.264698

- Žarić, Snježana (2005): Planktic foraminiferal flux of sediment trap WA1_trap, $652 \mathrm{~m}$ trap depth. Department of Geosciences, Bremen University, doi:10.1594/PANGAEA.264696

- Žarić, Snježana (2005): Planktic foraminiferal flux of sediment trap WA2_trap. Department of Geosciences, Bremen University, doi:10.1594/PANGAEA.264532
- Žarić, Snježana (2005): Planktic foraminiferal flux of sediment trap WA3_trap, $5031 \mathrm{~m}$ trap depth. Department of Geosciences, Bremen University, doi:10.1594/PANGAEA.264700

- Žarić, Snježana (2005): Planktic foraminiferal flux of sediment trap WAB1_trap, $4515 \mathrm{~m}$ trap depth. Department of Geosciences, Bremen University, doi:10.1594/PANGAEA.264754

- Žarić, Snježana (2005): Planktic foraminiferal flux of sediment trap WAB1_trap, $727 \mathrm{~m}$ trap depth. Department of Geosciences, Bremen University, doi:10.1594/PANGAEA.264747

- Žarić, Snježana (2005): Planktic foraminiferal flux of sediment trap WAB2_trap. Department of Geosciences, Bremen University, doi:10.1594/PANGAEA.264536

- Žarić, Snježana (2005): Planktic foraminiferal flux of sediment trap WR2_trap. doi:10.1594/PANGAEA.264542

- Žarić, Snježana (2005): Planktic foraminiferal flux of sediment trap WR3_trap. doi:10.1594/PANGAEA.264543

- Žarić, Snježana (2005): Planktic foraminiferal flux of sediment trap WR4_trap. doi:10.1594/PANGAEA.264544

- Žarić, Snježana (2005): Planktic foraminiferal flux of sediment trap WS1_trap. doi:10.1594/PANGAEA.264546

- Žarić, Snježana (2005): Planktic foraminiferal flux of sediment trap WS2_trap. doi:10.1594/PANGAEA.264547

- Žarić, Snježana (2005): Planktic foraminiferal flux of sediment trap WS3_trap. doi:10.1594/PANGAEA.264548

- Žarić, Snježana (2005): Planktic foraminiferal flux of sediment trap WS4_trap. doi:10.1594/PANGAEA.264549 
Acknowledgements. Funding was provided by the European Commission FP7 EURO-BASIN (European Basin-Scale Analysis, Synthesis, and Integration; grant agreement 264 933EU). Additional support was provided by the National Environment Research Council (UK) national capability funds. The authors are grateful to Cindy Lee, Susanne Neuer, Richard Lampitt and Eduard Bauerfeind for the provision of additional data to that already publicly available. We are also grateful to Ian Salter for useful comments on an earlier version of this manuscript, and to two anonymous reviewers for their comments, suggestions and criticism, which helped improve this manuscript. Most figures were produced using the software package ODV (Schlitzer, R., Ocean Data View, www.odv.awi.de, 2014).

Edited by: Y.-W. Luo

\section{References}

Antia, A. N., von Bodungen, B., and Peinert, R.: Particle flux across the mid-European continental margin, Deep-Sea Res. Pt. I, 46, 1999-2024, 1999.

Bahr, F., Kelly, R., Bates, N. R., Becker, S., Bell, S., Countway, P., Caporelli, E., Church, M. J., Close, A., Doyle, A., Gundersen, K., Hammer, M., Howse, F., Johnson, R., Goldthwait, S., Little, R., Morrison, R., Orcutt, K., Sanderson, M., SherriffDow, R., Sorensen, J., Stone, S., Rathbun, C., and Waterhouse, T.: Bermuda Atlantic Time-Series Study: Methods, Tech. Rep., 1997.

Bauerfeind, E. and Nöthig, E.-M.: Biogenic particle flux at AWI HAUSGARTEN from mooring FEVI3 at $2400 \mathrm{~m}$, Alfred Wegener Institute for Polar and Marine Research, Bremerhaven, Germany, 2011.

Bauerfeind, E., Noethig, E.-M., Beszczynska, A., Fahl, K., Kaleschke, L., Kreker, K., Klages, M., Soltwedel, T., Lorenzen, C., and Wegner, J.: Particle sedimentation patterns in the eastern Fram Strait during 2000-2005: Results from the Arctic long-term observatory HAUSGARTEN, Deep-Sea Res. Pt. I, 56, 1471-1487, 2009.

Bory, A. J. M. and Newton, P. P.: Transport of airborne lithogenic material down through the water column in two contrasting regions of the eastern subtropical North Atlantic Ocean, Global Biogeochem. Cy., 14, 297-315, 2000.

Bory, A., Jeandel, C., Leblond, N., Vangriesheim, A., Khripounoff, A., Beaufort, L., Rabouille, C., Nicolas, E., Tachikawa, K., and Etcheber, H.: Downward particle fluxes within different productivity regimes off the Mauritanian upwelling zone (EUMELI program), Deep-Sea Res. Pt. I, 48, 2251-2282, 2001.

DeMaster, D. J.: The Supply and Accumulation of Silica in the Marine-Environment, Geochim. Cosmochim. Ac., 45, 17151732, 1981.

Dymond, J. and Lyle, M.: Particle Fluxes in the Ocean and Implications for Sources and Preservation of Ocean Sediments, in: Material Fluxes on the Surface of the Earth, 125-142, The National Academies Press, 1994.

Dymond, J. and Lyle, M. W.: Particle fluxes of NAP_trap, 2003a. Dymond, J. and Lyle, M. W.: Particle fluxes of HAP-4_trap, 2003b. Eggimann, D. W., Manheim, F. T., and Betzer, P. R.: Dissolution and Analysis of Amorphous Silica in Marine Sediments, J. Sediment. Res., 50, 215-225, doi:10.1016/0967-0645(93)90034-K, 1980.
Eppley, R. W. and Peterson, B. J.: Particulate organic matter flux and planktonic new production in the deep ocean, Nature, 282, 677-680, 1979.

Fahl, K. and Nöthig, E.-M.: Lithogenic and biogenic particle fluxes on the Lomonosov Ridge (central Arctic Ocean) and their relevance for sediment accumulation: Vertical vs. lateral transport, Deep-Sea Res. Pt. I, 54, 1256-1272, 2007.

Fischer, G.: Particle fluxes of trap NU2, Geosciences, University of Bremen (GeoB), 2003a.

Fischer, G.: Flux data of trap WR2, Geosciences, University of Bremen (GeoB), 2003b.

Fischer, G.: Flux data of trap WR3, Geosciences, University of Bremen (GeoB), 2003c.

Fischer, G.: Flux data of trap WR4, Geosciences, University of Bremen (GeoB), 2003d.

Fischer, G.: Particle fluxes for the sampling interval, various ratios and major nutrients at the Atlantic/Southern Ocean trapping sites, Center for Marine Environmental Sciences (MARUM), 2005.

Fischer, G., Donner, B., Ratmeyer, V., Davenport, R., and Wefer, G.: Distinct year-to-year particle flux variations off Cape Blanc during 1988-1991: Relation to $\delta 180$-deduced sea-surface temperatures and trade winds, J. Mar. Res., 54, 73-98, 1996.

Fischer, G., Ratmeyer, V., and Wefer, G.: Organic carbon fluxes in the Atlantic and the Southern Ocean: relationship to primary production compiled from satellite radiometer data, Deep-Sea Res. Pt. II, 47, 1961-1997, 2000.

Fischer, G., Gersonde, R., and Wefer, G.: Organic carbon, biogenic silica and diatom fluxes in the marginal winter sea-ice zone and in the Polar Front Region: interannual variations and differences in composition, Deep-Sea Res. Pt. II, 49, 1721-1745, 2002.

Goutx, M., Momzikoff, A., Striby, L., Andersen, V., Marty, J., and Vescovali, I.: High-frequency fluxes of labile compounds in the central Ligurian Sea, northwestern Mediterranean, Deep-Sea Res. Pt. I, 47, 533-556, 2000.

Goutx, M., Wakeham, S. G., Lee, C., Duflos, M., Guigue, C., Liu, Z., Moriceau, B., Sempere, R., Tedetti, M., and Xue, J.: Composition and degradation of marine particles with different settling velocities in the northwestern Mediterranean Sea, Limnol. Oceanogr., 52, 1645-1664, 2007.

Helmke, P., Romero, O., and Fischer, G.: Northwest African upwelling and its effect on offshore organic carbon export to the deep sea, Global Biogeochem. Cy., 19, GB4015, doi:10.1029/2004GB002265, 2005.

Helmke, P., Neuer, S., Lomas, M. W., Conte, M., and Freudenthal, T.: Cross-basin differences in particulate organic carbon export and flux attenuation in the subtropical North Atlantic gyre, DeepSea Res. Pt. I, 57, 213-227, 2010.

Honjo, S. and Doherty, K.: Large aperture time-series sediment traps; design objectives, construction and application, Deep-Sea Res., 35, 133-149, 1988.

Honjo, S. and Manganini, S.: Annual biogenic particle fluxes to the interior of the North Atlantic Ocean; studied at $34^{\circ} \mathrm{N} 21^{\circ} \mathrm{W}$ and $48^{\circ} \mathrm{N} 21^{\circ} \mathrm{W}$, Deep-Sea Res. Pt. II, 40, 587-607, 1993.

Honjo, S. and Manganini, S. J.: Annual Particle fluxes of NABEN34_trap, Woods Hole Oceanographic Institution, USA: U.S. JGOFS Data Management Office, 2003a. 
Honjo, S. and Manganini, S. J.: Biogenic particle flux of trap NABE-N34.1, Woods Hole Oceanographic Institution, USA: U.S. JGOFS Data Management Office, 2003b.

Honjo, S. and Manganini, S. J.: Biogenic particle flux of trap NABE-N34.2, Woods Hole Oceanographic Institution, USA: U.S. JGOFS Data Management Office, 2003c.

Honjo, S. and Manganini, S. J.: Annual Particle fluxes of NABEN48_trap, Woods Hole Oceanographic Institution, USA: U.S. JGOFS Data Management Office, 2003d.

Honjo, S. and Manganini, S. J.: Biogenic particle flux of trap NABE-N48.1, Woods Hole Oceanographic Institution, USA: U.S. JGOFS Data Management Office, 2003e.

Honjo, S. and Manganini, S. J.: Biogenic particle flux of trap NABE-N48.2, Woods Hole Oceanographic Institution, USA: U.S. JGOFS Data Management Office, 2003f.

Hwang, J., Manganini, S. J., Montlucon, D. B., and Eglinton, T. I.: Dynamics of particle export on the Northwest Atlantic margin, Deep-Sea Res. Pt. I, 56, 1792-1803, 2009.

Irwin, B.: POC, PON, chlorophyll, phaeophytin of BAF89/3_FTRAP1, Marine Environmental Data Service, Department of Fisheries and Oceans, Canada, 2002a.

Irwin, B.: POC, PON, chlorophyll, phaeophytin of BAF89/3_FTRAP2, Marine Environmental Data Service, Department of Fisheries and Oceans, Canada, 2002b.

Iversen, M. H., Nowald, N., Ploug, H., Jackson, G. A., and Fischer, G.: High resolution profiles of vertical particulate organic matter export off Cape Blanc, Mauritania: Degradation processes and ballasting effects, Deep-Sea Res. Pt. I, 57, 771-784, 2010.

Jickells, T., Newton, P., King, P., Lampitt, R., and Boutle, C.: A comparison of sediment trap records of particle fluxes from 19 to $48^{\circ} \mathrm{N}$ in the northeast Atlantic and their relation to surface water productivity, Deep-Sea Res. Pt. I, 43, 971-986, 1996.

Jickells, T. D.: Particle fluxes of $19^{\circ} \mathrm{N} 20^{\circ} \mathrm{W}$ trap, 2003a.

Jickells, T. D.: Particle fluxes of $24^{\circ} \mathrm{N} 23^{\circ}$ W_trap, 2003b.

Jickells, T. D.: Particle fluxes of $28^{\circ} \mathrm{N} 22^{\circ}$ W_trap, 2003c.

Jickells, T. D.: Particle fluxes of Parflux7G_trap, 2003d.

Jonkers, L., Brummer, G.-J. A., Peeters, F. J. C., van Aken, H. M., and De Jong, M. F.: Seasonal stratification, shell flux, and oxygen isotope dynamics of left-coiling N. pachydermaand T. quinquelobain the western subpolar North Atlantic, Paleoceanography, 25, PA2204, doi:10.1029/2009PA001849, 2010.

Koning, E., Epping, E., and Van Raaphorst, W.: Determining Biogenic Silica in Marine Samples by Tracking Silicate and Aluminium Concentrations in Alkaline Leaching Solutions, Aquat. Geochem., 8, 37-67, 2002.

Kremling, K., Lentz, U., Zeitzschel, B., Bull, D. E. S., and Duinker, J. C.: New type of timeseries sediment trap for the reliable collection of inorganic and organic trace chemical substances, Rev. Sci. Instrum., 67, 4360-4363, 1996.

Lampitt, R. and Antia, A.: Particle flux in deep seas: regional characteristics and temporal variability, Deep-Sea Res. Pt. I, 44, 1377-1403, 1997.

Lampitt, R. S., Bett, B. J., Kiriakoulakis, K., Popova, E. E., Ragueneau, O., Vangriesheim, A., and Wolff, G. A.: Material supply to the abyssal seafloor in the Northeast Atlantic, Prog. Oceanogr., 50, 27-63, 2001.

Lampitt, R. S., Salter, I., de Cuevas, B. A., Hartman, S., Larkin, K. E., and Pebody, C. A.: Long-term variability of downward particle flux in the deep northeast Atlantic: Causes and trends, Deep-Sea Res. Pt. II, 57, 1346-1361, 2010.

Laws, E. A., Falkowski, P. G., Smith Jr., W. O., Ducklow, H., and McCarthy, J. J.: Temperature effects on export product in the open ocean, Global Biogeochem. Cy., 14, 1231-1246, 2000.

Lee, C., Armstrong, R. A., Cochran, J. K., Engel, A., Fowler, S. W., Goutx, M., Masque, P., Miquel, J. C., Peterson, M., Tamburini, C., and Wakeham, S.: MedFlux: Investigations of particle flux in the Twilight Zone, Deep-Sea Res. Pt. II, 56, 1363-1368, 2009a.

Lee, C., Peterson, M. L., Wakeham, S. G., Armstrong, R. A., Cochran, J. K., Miquel, J. C., Fowler, S. W., Hirschberg, D., Beck, A., and Xue, J.: Particulate organic matter and ballast fluxes measured using time-series and settling velocity sediment traps in the northwestern Mediterranean Sea, Deep-Sea Res. Pt. II, 56, 1420-1436, 2009b.

Lisitsyn, A. P., Shevchenko, V. P., Vinogradov, M. E., Severina, O. V., Vavilova, V. V., and Mitskevich, I. N.: Particle fluxes in the Kara Sea dn Ob and Yenisey estuaries, Oceanology, 34, 683693, 1995.

Martin, J.: Particle interceptor data of sediment trap AT_II119/4_Trap_A, Woods Hole Oceanographic Institution, USA, 2003a.

Martin, J.: Particle interceptor data of sediment trap AT_II119/4_Trap_B, Woods Hole Oceanographic Institution, USA, $2003 b$.

Martin, J.: Particle interceptor data of sediment trap AT_II119/5_Trap_C, Woods Hole Oceanographic Institution, USA, 2003c.

Miquel, J. C., Martin, J., Gasser, B., Rodriguez-y Baena, A., Toubal, T., and Fowler, S. W.: Dynamics of particle flux and carbon export in the northwestern Mediterranean Sea: a two decade timeseries study at the DYFAMED site, Prog. Oceanogr., 91, 461481, 2011.

Montes, E., Müller-Karger, F., Thunell, R., Hollander, D., Astor, Y., Varela, R., Soto, I., and Lorenzoni, L.: Vertical fluxes of particulate biogenic material through the euphotic and twilight zones in the Cariaco Basin, Venezuela, Deep-Sea Res. Pt. I, 67, 73-84, 2012.

Mortlock, R. A. and Froelich, P. N.: A simple method for the rapid determination of biogenic opal in pelagic marine sediments, Mar. Chem., 36, 1415-1426, 1989.

Müller, P. J. and Schneider, R.: An automated leaching method for the determination of opal in sediments and particulate matter, Deep-Sea Res. Pt. I, 40, 425-444, 1993.

Neuer, S., Ratmeyer, V., Davenport, R., Fischer, G., and Wefer, G.: Deep water particle flux in the Canary Island region: seasonal trends in relation to long-term satellite derived pigment data and lateral sources, Deep-Sea Res. Pt. I, 44, 1451-1466, 1997.

Neuer, S., Cianca, A., Helmke, P., Freudenthal, T., Davenport, R., Meggers, H., Knoll, M., Santana-Casiano, J. M., Gonz alez Davila, M., Rueda, M.-J. E., and Llin as, O.: Biogeochemistry and hydrography in the eastern subtropical North Atlantic gyre. Results from the European time-series station ESTOC, Prog. Oceanogr., 72, 1-29, 2007.

Newton, P. P., Lampitt, R. S., Jickells, T. D., King, P., and Boutle, C.: Temporal and spatial variability of biogenic particles fluxes during the JGOFS northeast Atlantic process studies at $47^{\circ} \mathrm{N}$, 20 W, Deep-Sea Res. Pt. I, 41, 1617-1642, 1994. 
NGOFS and Tande, K.: Particle flux of drift station JM9-1, PANGAEA, 2003.

OMEX and Wassmann, P.: Fluxes of trap JM3_DRIFT1, PANGAEA, 2004a.

OMEX and Wassmann, P.: Fluxes of trap JM4_DRIFT1, PANGAEA, 2004b.

OMEX and Wassmann, P.: Fluxes of trap JM5_DRIFT1, PANGAEA, 2004c.

OMEX and Wassmann, P.: Fluxes of trap JM6_DRIFT1, PANGAEA, 2004d.

OMEX and Wassmann, P.: Fluxes of trap JM7_DRIFT1, PANGAEA, 2004e.

OMEX and Wassmann, P.: Fluxes of trap JM9_DRIFT1, PANGAEA, 2004f.

OMEX and Wassmann, P.: Fluxes of trap JM10_DRIFT2, PANGAEA, 2004g.

OMEX and Wassmann, P.: Fluxes of trap JM11_DRIFT1, PANGAEA, 2004h.

Peinert, R., Antia, A., Bauerfeind, E., von Bodungen, B., Haupt, O., Krumbholz, M., Peeken, I., Ramseier, R. O., Voß, M., and Zeitzschel, B.: Particle flux variability in the polar and Atlantic provinces of the Nordic Seas, in: The Northern North Atlantic: A Changing Environment, 53-68, Springer Verlag, 2001.

Peterson, M., Wakeham, S., Lee, C., Askea, M., and Miquel, J.: Novel techniques for collection of sinking particles in the ocean and determining their settling rates, Limnol. Oceanogr.-Meth., 3, 520-532, 2005.

Peterson, M. L., Fabres, J., Wakeham, S. G., Lee, C., Alonso, I. J., and Miquel, J. C.: Sampling the vertical particle flux in the upper water column using a large diameter free-drifting NetTrap adapted to an Indented Rotating Sphere sediment trap, Deep-Sea Res. Pt. II, 56, 1547-1557, 2009.

Raab, A.: Sedimente des Changeable-Sees, OktoberrevolutionsInsel (Severnaja Zemlja), als Archive der Paläoumwelt Mittelsibiriens seit dem Frühweichsel = Changeable lake sediments, October Revolution Island (Severnaya Zemlya), as an archive for the environmental history in central Siberia since the early Weichselian, Berichte zur Polar- und Meeresforschung (Reports on Polar and Marine Research), Bremerhaven, Alfred Wegener Institute for Polar and Marine Research, 435, p. 115, 2003.

Ragueneau, O., Gallinari, M., Corrin, L., Grandel, S., Hall, P., Hauvespre, A., Lampitt, R., Rickert, D., Stahl, H., and Witbaard, A. T. R.: The benthic silica cycle in the Northeast Atlantic: annual mass balance, seasonality, and importance of non-steadystate processes for the early diagenesis of biogenic opal in deep-sea sediments, Prog. Oceanogr., 50, 171-200, 2001.

Romero, O., Boeckel, B., Lavik, G., Fischer, G., and Wefer, G.: Seasonal productivity dynamics in the pelagic central Benguela System inferred from the flux of carbonate and silicate organisms, J. Marine Syst., 37, 259-278, 2002.
Rudnick, R. L. and Gao, S.: Composition of the Continental Crust, in: Treatise on Geochemistry, 1-64, Elsevier, 2003.

Salter, I., Kemp, A. E. S., Lampitt, R. S., and Gledhill, M.: The association between biogenic and inorganic minerals and the amino acid composition of settling particles, Limnol. Oceanogr., 55, 2207-2218, 2010.

Sanders, R., Henson, S., Koski, M., De La Rocha, C., Painter, S. C., Poulton, A., Riley, J., Salihoglu, B., Visser, A., Yool, A., Bellerby, R., and Martin, A.: The Biological Carbon Pump in the North Atlantic, Prog. Oceanogr., accepted, 2014.

Shevchenko, V. P.: tab1+2, PANGAEA, 2000.

Soutar, A., Kling, S. A., Crill, P. A., Duffrin, E., and Bruland, K. W.: Monitoring the marine environment through sedimentation, Nature, 266, 136-139, 1977.

Stein, R.: Modern and late quaternary depositional environment of the St. Anna Trough Area, Northern Kara Sea, Berichte zur Polarforschung (Reports on Polar Research), Tech. Rep. 342, Alfred Wegener Institute for Polar and Marine Research, Bremerhaven, 1999.

Tett, P.: Flux values of different LOIS-Trap Sites, PANGAEA, 2005.

Thomsen, C. and von Bodungen, B.: tab 3.2.1+2 Vertical particle flux and alkenones in mooring OG4, PANGAEA, 2001a.

Thomsen, C. and von Bodungen, B.: tab 3.1.1+2 Vertical particle flux and alkenones in mooring NB6, 2001b.

Thomsen, C. and von Bodungen, B.: tab 3.3.1+2 Vertical particle flux and alkenones in mooring BI2, PANGAEA, 2001c.

von Bodungen, B., Antia, A., Bauerfeind, E., Haupt, O., Koeve, W., Machado, E., Peeken, I., Peinert, R., Reitmeier, S., Thomsen, C., Voss, M., Wunsch, M., Zeller, U., and Zeitzschel, B.: Pelagic processes and vertical flux of particles: an overview of a long-term comparative study in the Norwegian Sea and Greenland Sea, Geol. Rundsch., 84, 11-27, 1995.

Waniek, J., Schulz-Bull, D., Kuss, J., and Blanz, T.: Long time series of deep water particle flux in three biogeochemical provinces of the northeast Atlantic, J. Marine Syst., 56, 391-415, 2005.

Wedepohl, H. K.: The composition of the continental crust, Geochim. Cosmochim. Ac., 59, 1217-1232, 1995.

Wefer, G. and Fischer, G.: Annual primary production and export flux in the Southern Ocean from sediment trap data, Mar. Chem., 35, 597-613, 1991.

Wefer, G. and Fischer, G.: Seasonal patterns of vertical particle flux in equatorial and coastal upwelling areas of the eastern Atlantic, Deep-Sea Res. Pt. I, 40, 1613-1645, 1993.

Žarić, S., Donner, B., Fischer, G., Mulitza, S., and Wefer, G.: Sensitivity of planktic foraminifera to sea surface temperature and export production as derived from sediment trap data, Mar. Micropaleontol., 55, 75-105, 2005.

Zeitzschel, B., Diekmann, P., and Uhlmann, L.: A new multisample sediment trap, Mar. Biol., 45, 285-288, 1978. 